\title{
Radiation In-Port Cross-Talks of ITER Port Diagnostics
}

\author{
A. Serikov ${ }^{1}$, U. Fischer ${ }^{1}$, D. Anthoine ${ }^{2}$, L. Bertalot ${ }^{3}$, M. De Bock ${ }^{3}$, R. O'Connor ${ }^{3}$, R. Juarez ${ }^{4}$, V. Krasilnikov ${ }^{3}$ \\ ${ }^{1}$ Karlsruhe Institute of Technology (KIT), Institute for Neutron Physics and Reactor Technology, Hermann- \\ von-Helmholtz-Platz 1, 76344 Eggenstein-Leopoldshafen, Germany \\ ${ }^{2}$ Bertin Technologies, France \\ 3ITER Organization, Route de Vinon-sur-Verdon, CS 90 046, 13067 St. Paul Lez Durance Cedex, France \\ ${ }^{4}$ Departamento de Ingeniería Energética, ETSII-UNED, Calle Juan del Rosal 12, Madrid 28040, Spain
}

Email corresponding author: arkady.serikov@kit.edu 


\section{Content}

- Objectives (phenomenon of radiation cross-talks between Diagnostic systems)

- Examples of in-port cross-talks:

1) Tritium and Deposition Monitor (TDM) \& CIXS in Local model of EPP \#17

2) Tangential Neutron Spectrometer (TNS) inside the EPP \#8 with 7 Diagnostics in C-lite v.2

3) Shutter and the main Diagnostic path of the Charge eXchange Recombination Spectroscopy (CXRS) in UPP \#3

- Conclusions 


\section{In-port radiation cross-talks}

\section{Example 1: Tritium and Deposition Monitor (TDM) \& CIXS in Local model of EPP \#17}




\section{MCNP Local modeling approach and mesh-tallies}

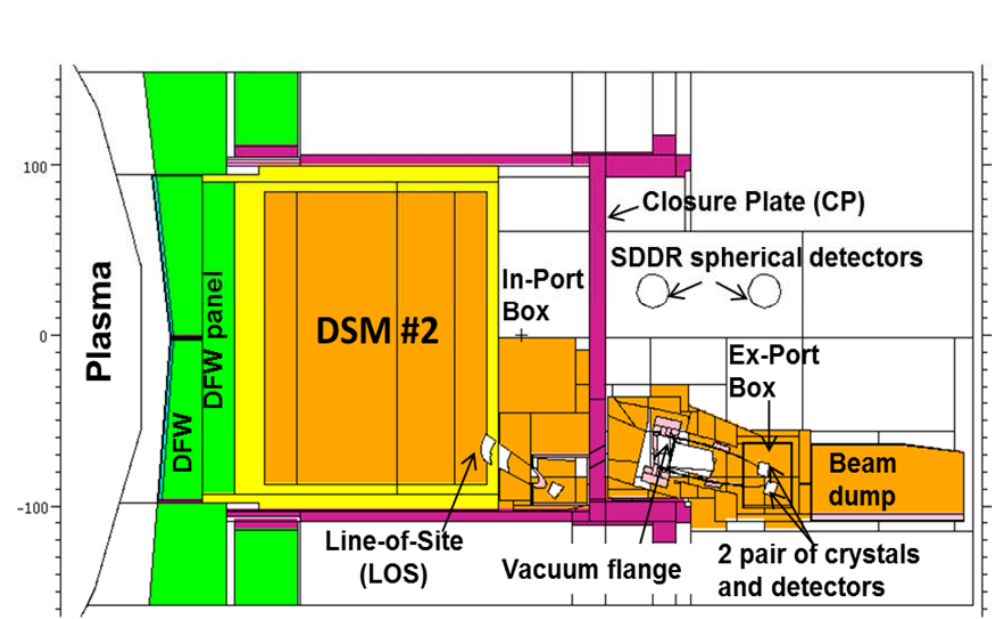

Initial MCNP local model of the CIXS Diagnostics apertures only

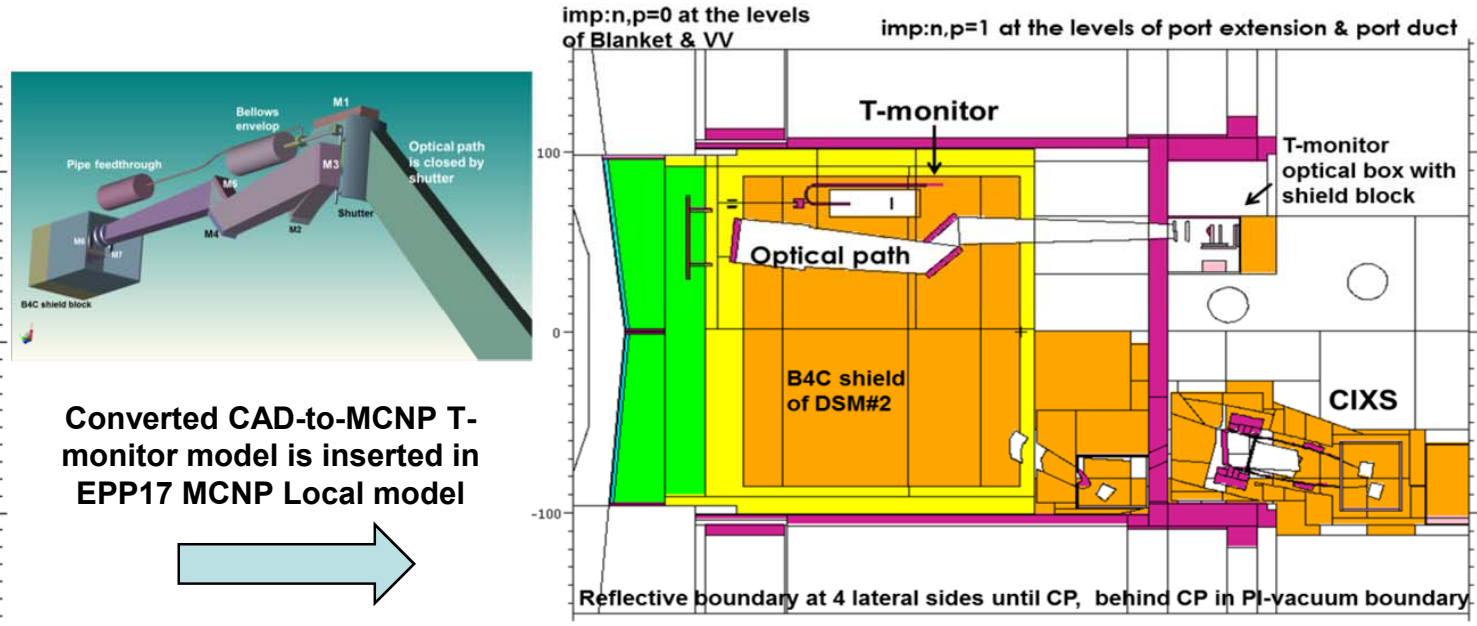

Resulting MCNP local model with Diagnostics apertures of two systems: Tritium (T) monitor \& CIXS

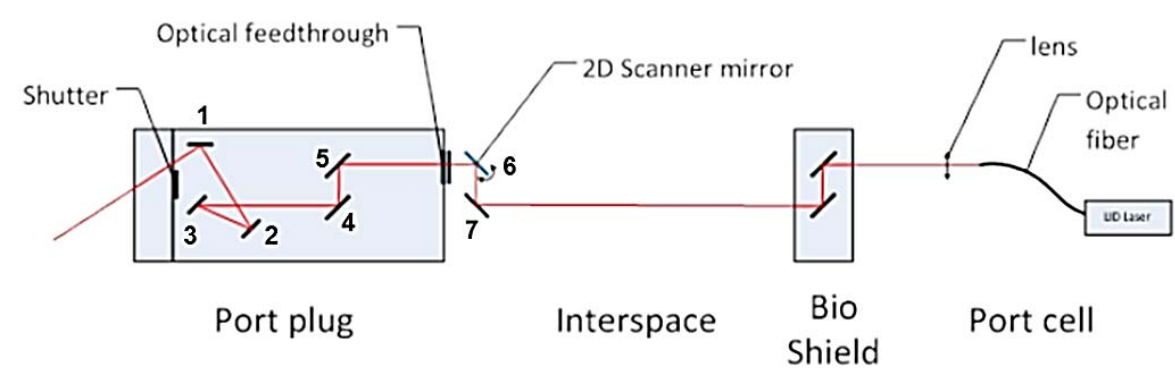

7 mirrors M1-M7 have been modelled - along the optical pathway, started from the front mirror M1, ended by M7 inside the optical box attached to the Closure Plate

DFw" $\mathrm{V}$ " shape is the old version but we supposed this has no impact on the presented results

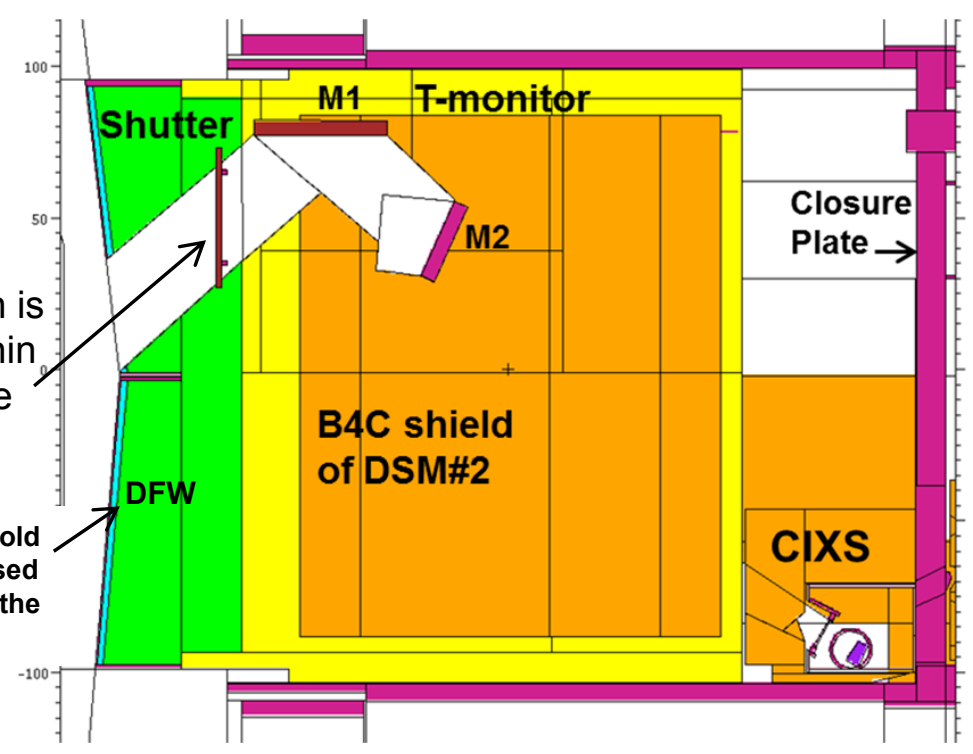




\section{Total neutron flux for EPP17 with CIXS only}

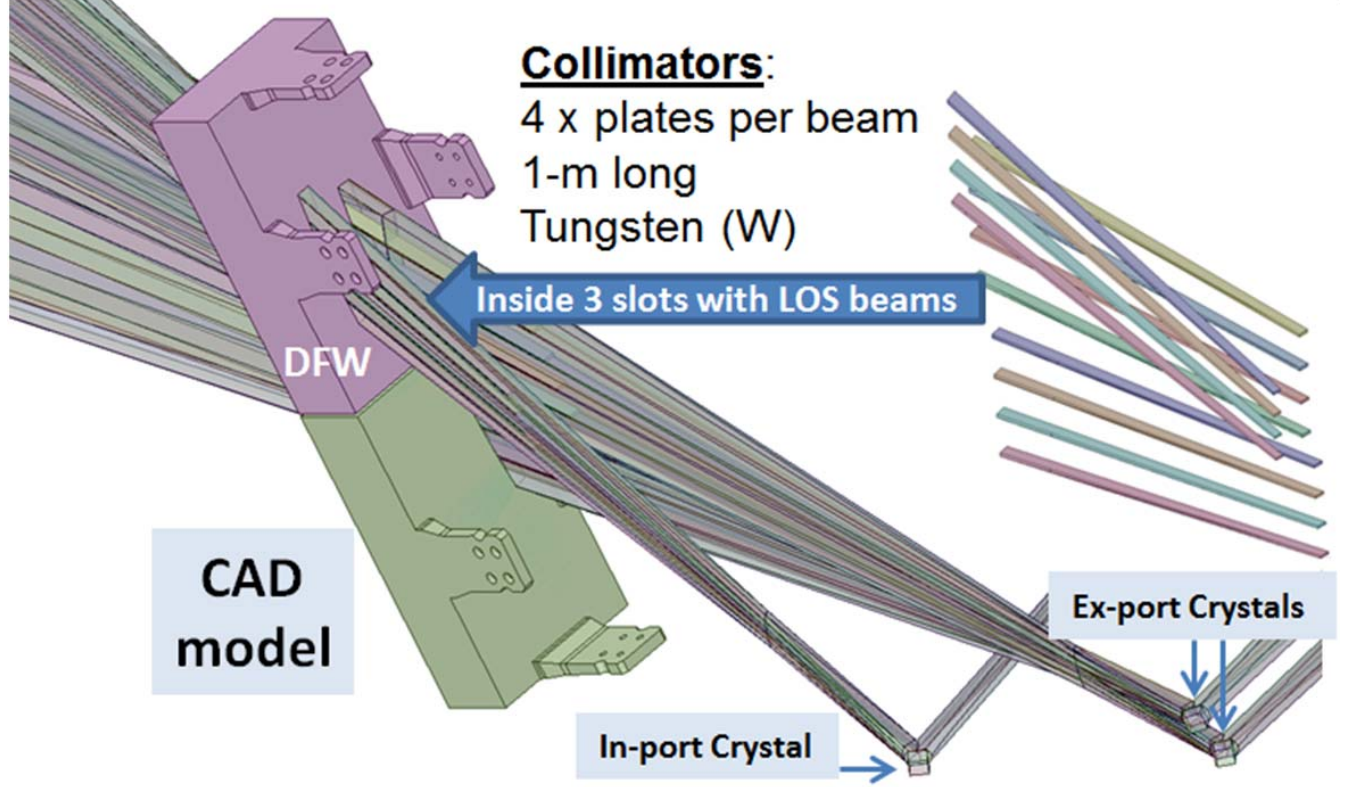

CAD model of the original CIXS shielding

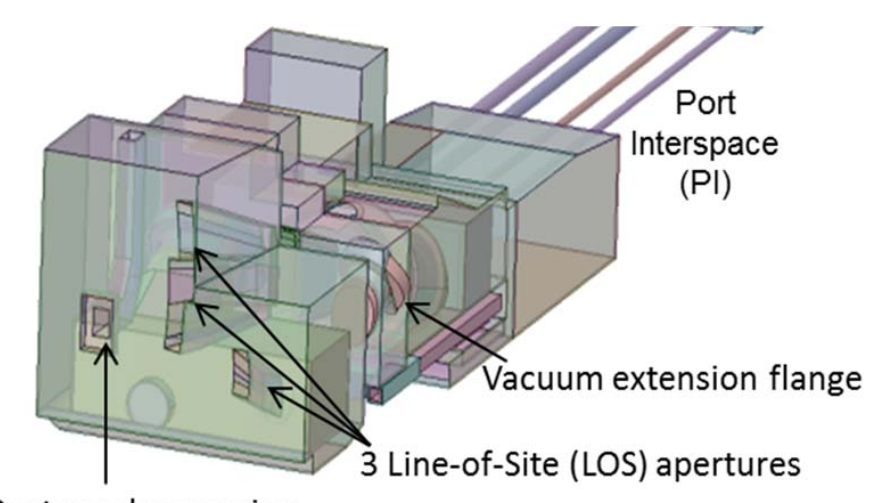

Rectangular opening

reserved for NAS

Map of total $n$-flux for the CIXS model having no-collimated LOS beams

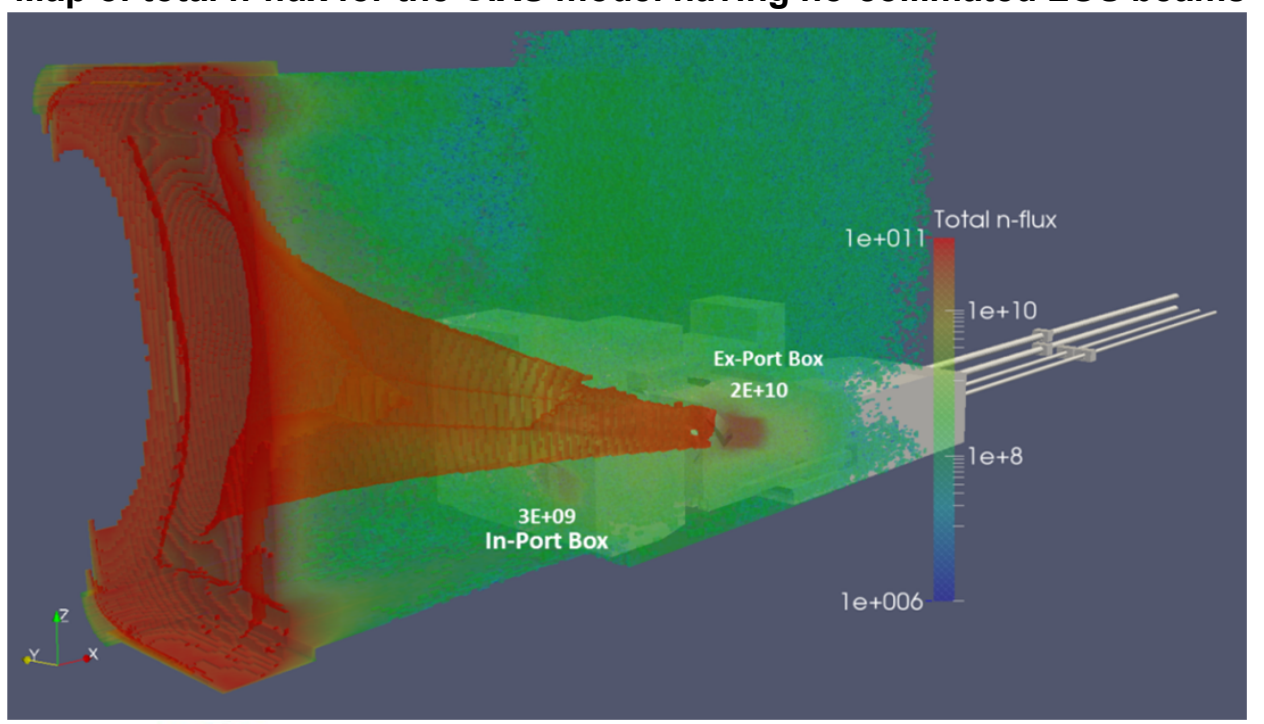

Map of total $n$-flux for the CIXS model with collimated LOS beams

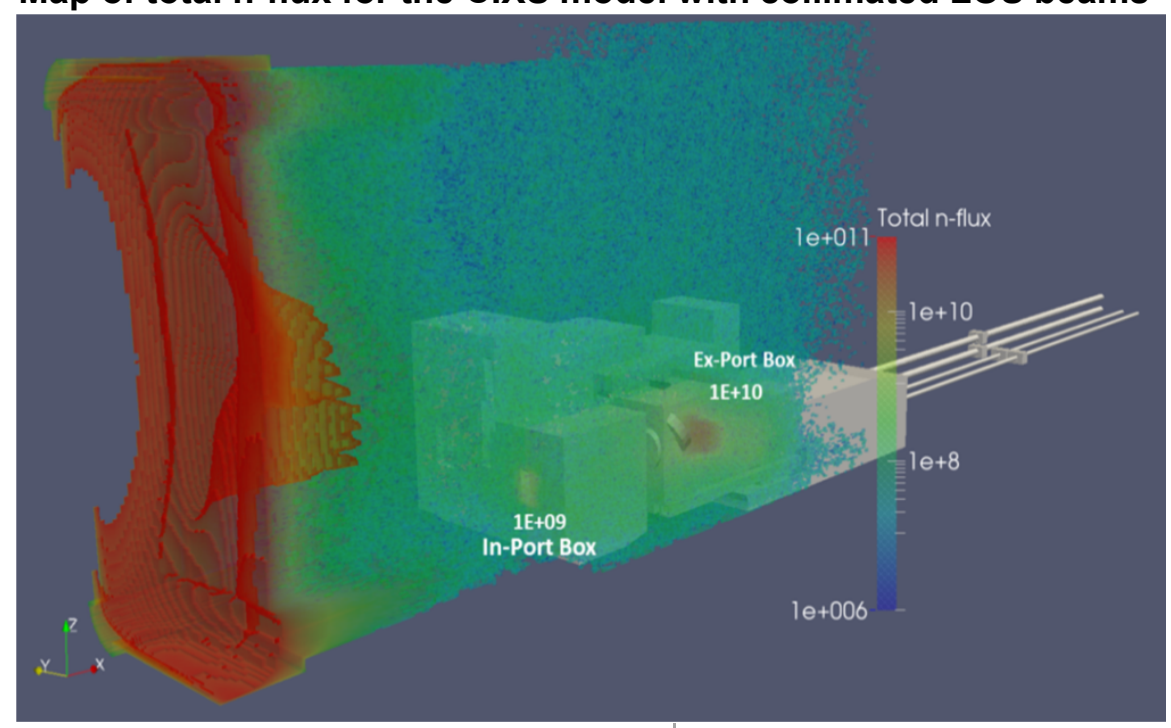

Radiation In-Port Cross-Talks for ITER Port Diagnostics, 22 ${ }^{\text {nd }}$ TOF,

Page 5 Philadelphia, 22 - 25 August 2016 


\section{Total neutron flux for EPP17 with CIXS and TD-monitor}

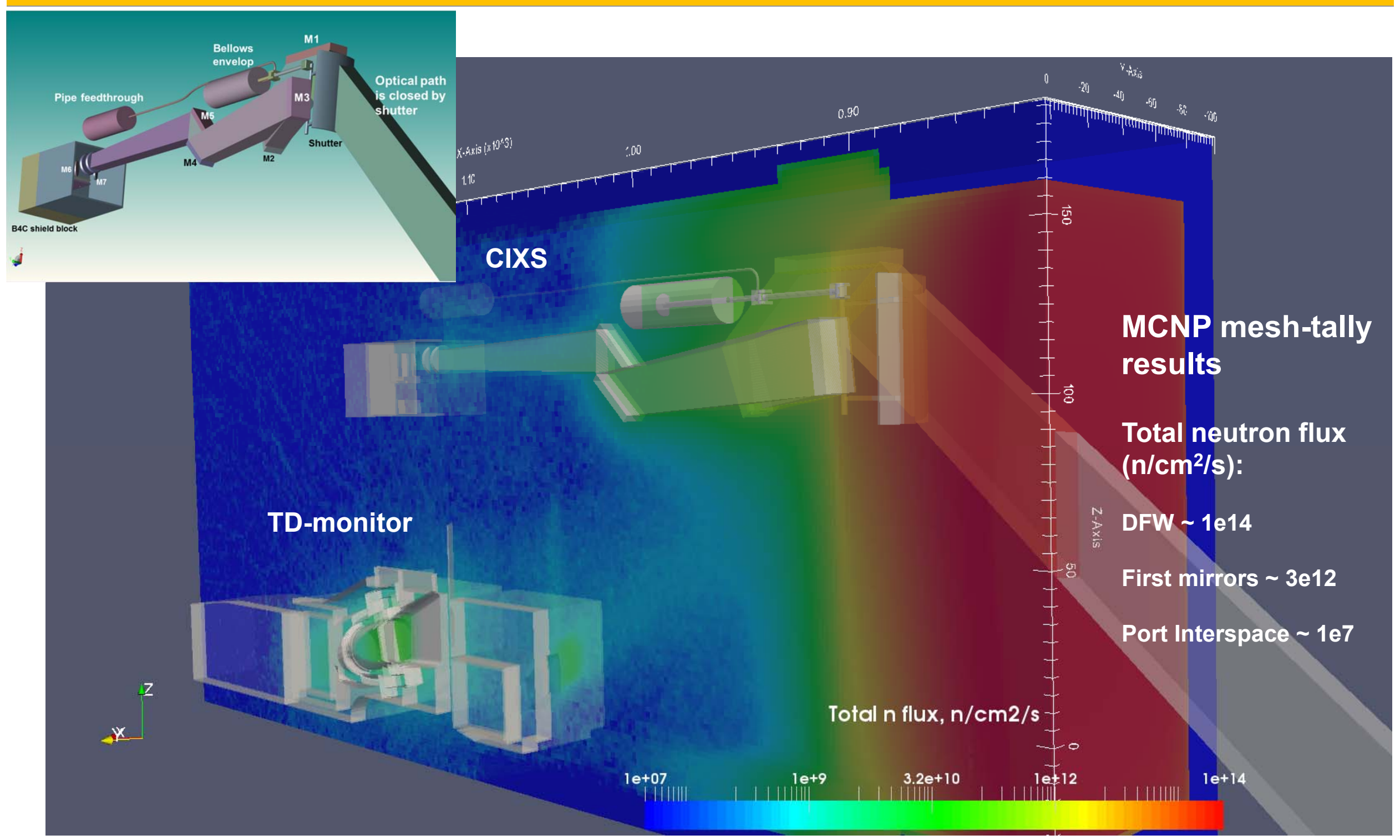




\section{Too small vertical shift in a bend segment M4-M5}

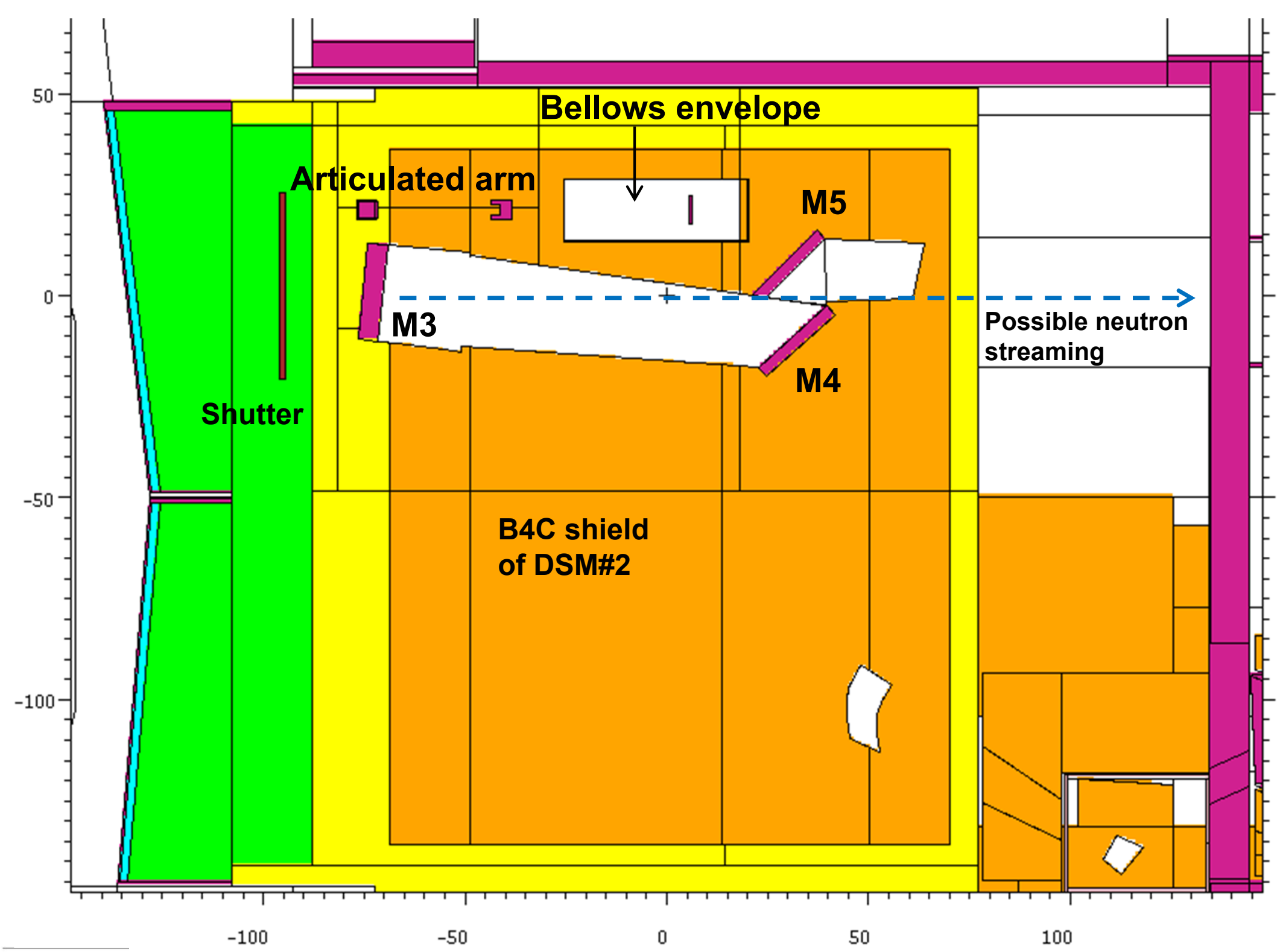

Radiation In-Port Cross-Talks for ITER Port Diagnostics, 22nd TOFE, 


\section{Neutron and gamma loads on the TD-monitor mirrors}

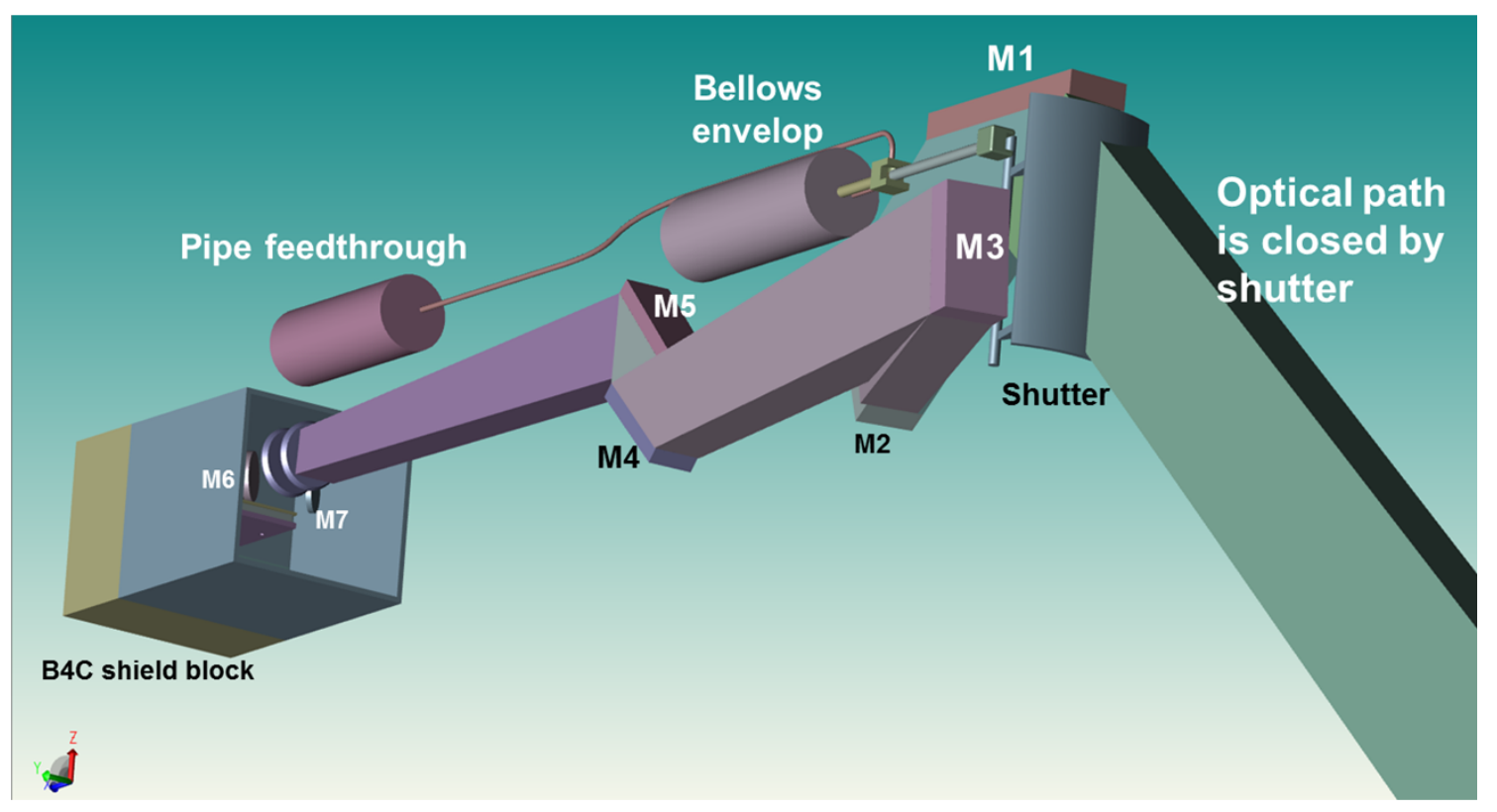

Neutron loads on mirrors

\section{Summary table of the neutronic loads on mimors - fluxes and nuc lear heat averaged over the minor volumes}

\begin{tabular}{|c|c|c|c|c|c|c|c|c|}
\hline $\begin{array}{l}\text { MCNP cell } \\
\text { number }\end{array}$ & $\begin{array}{l}\text { Mirror } \\
\text { number }\end{array}$ & Material & $\begin{array}{l}\text { Volume, } \\
\text { cm3 }\end{array}$ & $\begin{array}{l}\text { Total neutron } \\
\text { flux, } \mathrm{n} / \mathrm{cm} 2 / \mathrm{s}\end{array}$ & $\begin{array}{l}\text { Total gamma flux, } \\
\text { gamma/ cm2/s }\end{array}$ & $\begin{array}{l}\text { Neutron } \\
\text { heating, } \\
\mathrm{W} / \mathrm{cm} 3\end{array}$ & $\begin{array}{l}\text { Gamma } \\
\text { heating, } \\
\mathrm{W} / \mathrm{cm} 3\end{array}$ & $\begin{array}{c}\text { Total }(\mathrm{n}+\text { gamma) } \\
\text { heating, } \mathrm{W} / \mathrm{cm} 3\end{array}$ \\
\hline Cell 18554 & M1 & Molybdenum (Mo) & 2640.81 & $3.14 \mathrm{E}+12$ & $1.29 \mathrm{E}+12$ & $3.11 \mathrm{E}-02$ & $7.42 \mathrm{E}-01$ & 7.73E-01 \\
\hline Cell 18555 & $\mathrm{M} 2$ & St. steel (SS316L(N)-IG) & 1485.23 & $3.22 \mathrm{E}+11$ & $1.48 \mathrm{E}+11$ & $2.98 \mathrm{E}-03$ & 3.87E-02 & 4.17E-02 \\
\hline Cell 18618 & M3 & St. steel (SS316L(N)-IG) & 1360.83 & $3.51 \mathrm{E}+12$ & $8.54 \mathrm{E}+11$ & $2.21 \mathrm{E}-02$ & $2.88 \mathrm{E}-01$ & $3.10 \mathrm{E}-01$ \\
\hline Cell 18556 & M4 & St. steel (SS316L(N)-IG) & 601.99 & $2.52 \mathrm{E}+10$ & $1.39 \mathrm{E}+10$ & $3.48 \mathrm{E}-04$ & 3.99E-03 & 4.34E-03 \\
\hline Cell 18559 & M5 & St. steel (SS316L(N)-IG) & 567.48 & $5.85 \mathrm{E}+09$ & $5.31 \mathrm{E}+09$ & 8.50E-05 & 1.63E-03 & 1.71E-03 \\
\hline Cell 18557 & M6 & St. steel (SS316L(N)-IG) & 85.49 & $2.47 \mathrm{E}+08$ & $9.25 \mathrm{E}+07$ & 4.24E-06 & 4.18E-05 & 4.60E-05 \\
\hline Cell 18558 & $\mathrm{M7}$ & St. steel $(\mathrm{SS} 316 \mathrm{~L}(\mathrm{~N})-\mathrm{IG})$ & 50.33 & $6.07 \mathrm{E}+07$ & $1.44 \mathrm{E}+07$ & 8.97E-07 & 4.75E-06 & $5.65 \mathrm{E}-06$ \\
\hline
\end{tabular}

For all the presented results in mirrors, the statistical uncertainty expressed in Monte Carlo MCNP relative errors are less then $1 \%$ for the mirrors M1-M5, and around $10 \%$ for the mirrors M6-M7 behind the Closure Plate. 


\section{Distribution of decay gamma sources for SDDR}
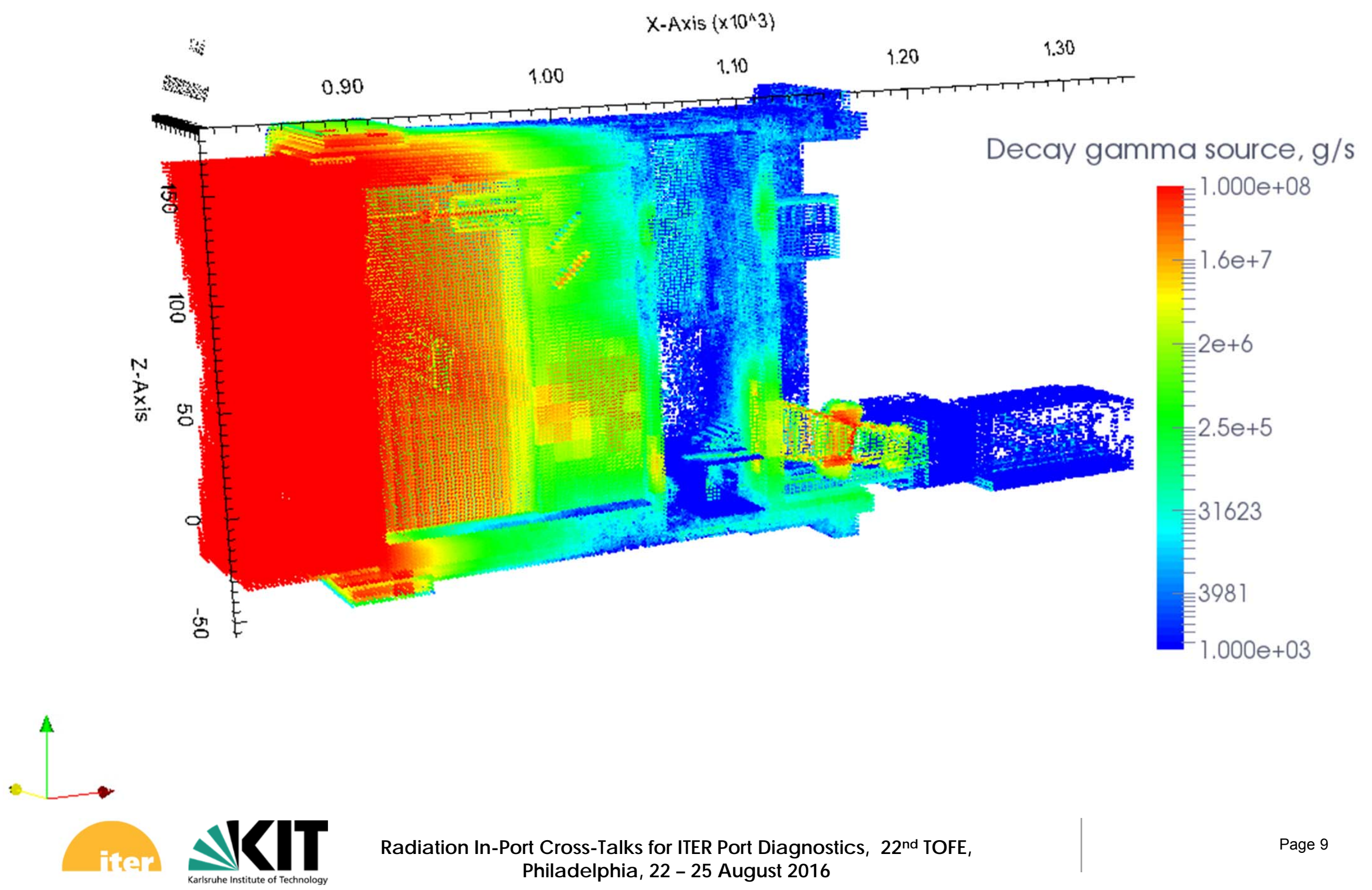
SDDR (Sv/h) map thresholded between $\mathbf{3 0 0}$ microSv/h (at contact with flange) and $\mathbf{5 0} \mathbf{~ m i c r o S v} / \mathbf{h}$ (dose level of maintenance access) - radial extent (X-axis) for CIXS without shield

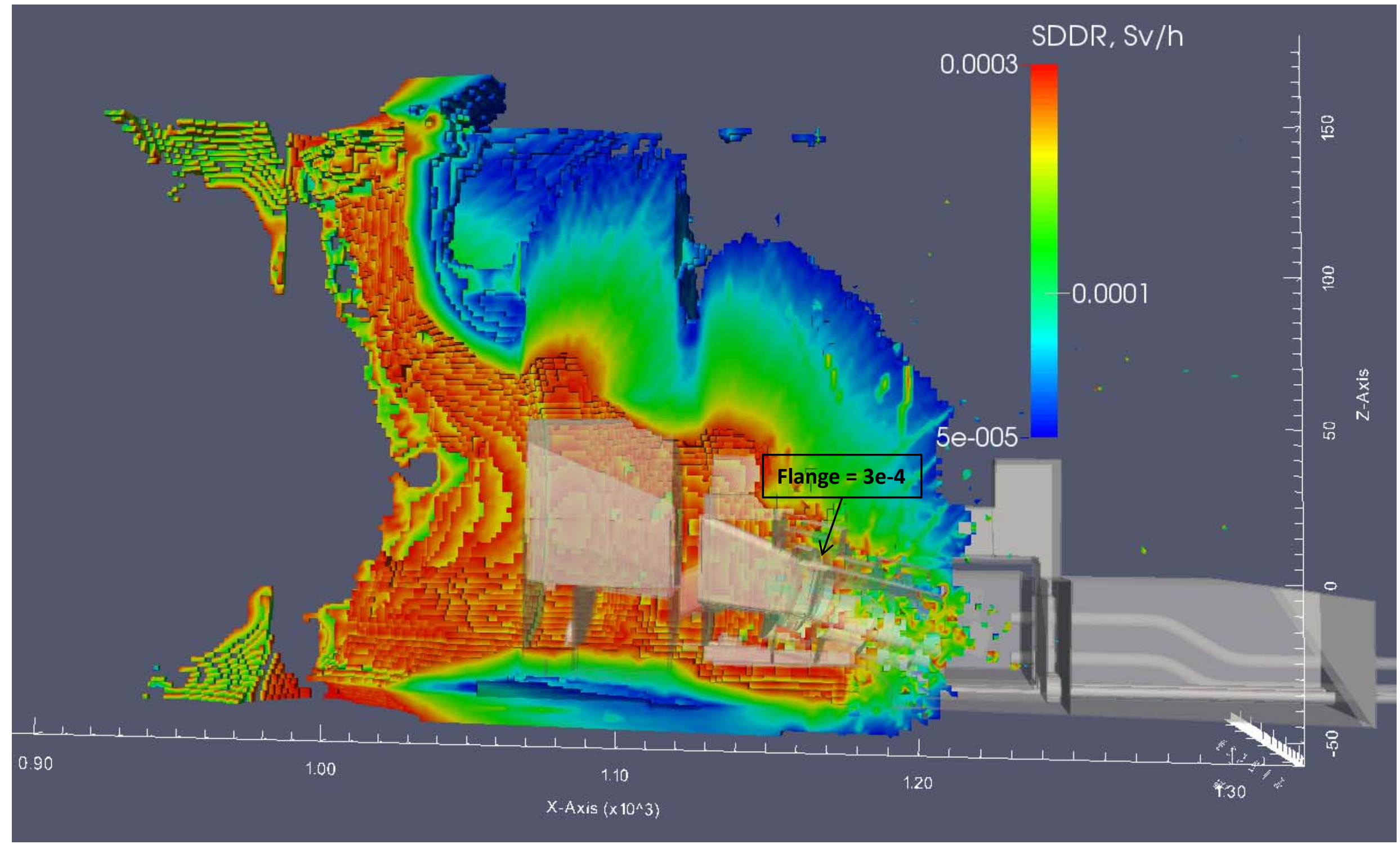

Axis coordinates in $\mathbf{~ c m}$ 


\section{SDDR for EPP17 with 2 diagnostics systems integrated: TD-monitor and CIXS}

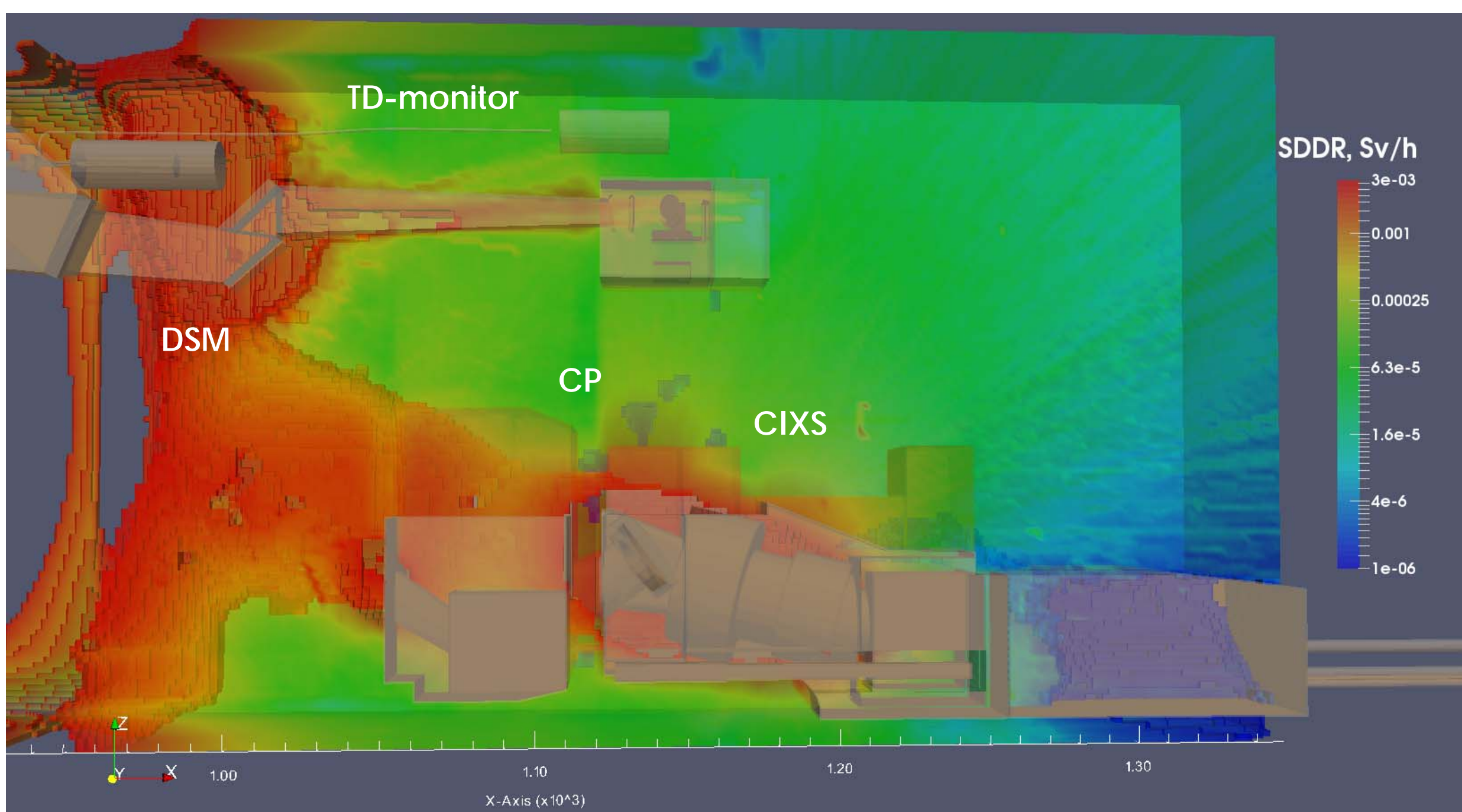




\section{Comparison of the SDDR distributions in MCNP fine mesh}

SDDR in CIXS-only model

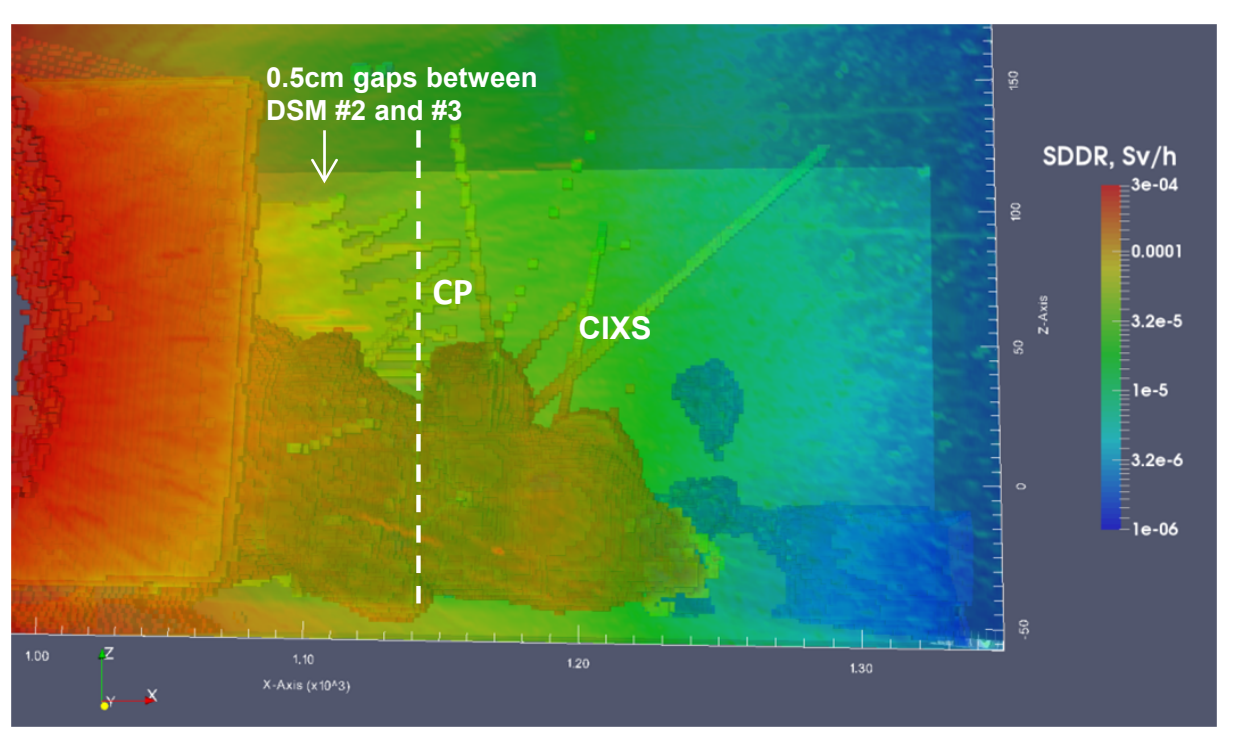

vs. SDDR in TD-monitor \& CIXS model

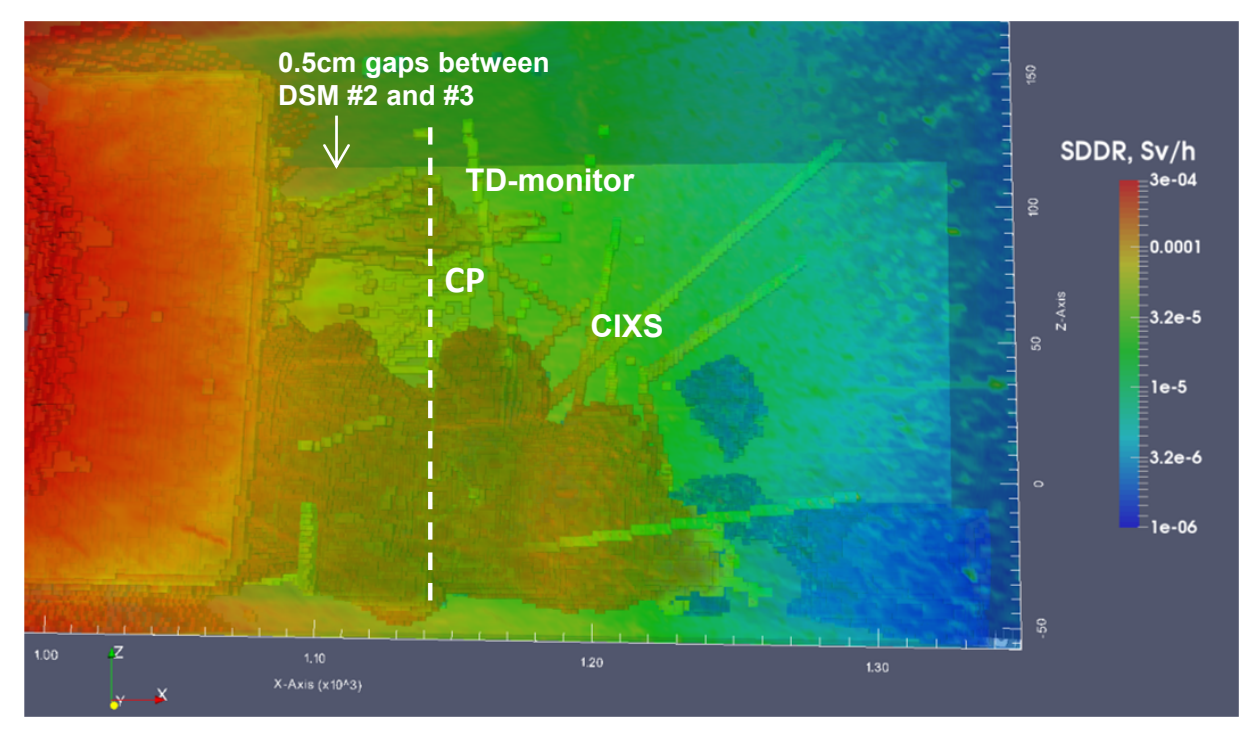

Decay gamma streaming pathways:

1) $0.5 \mathrm{~cm}$ gaps between DSM \#2 and \#3

2) CIXS

Decay gamma streaming pathways:

1) $0.5 \mathrm{~cm}$ gaps between DSM \#2 and \#3

2) $\mathrm{CIXS}$

3) TD-monitor 


\section{SDDR comparison in spherical detectors in PI of EPP17}

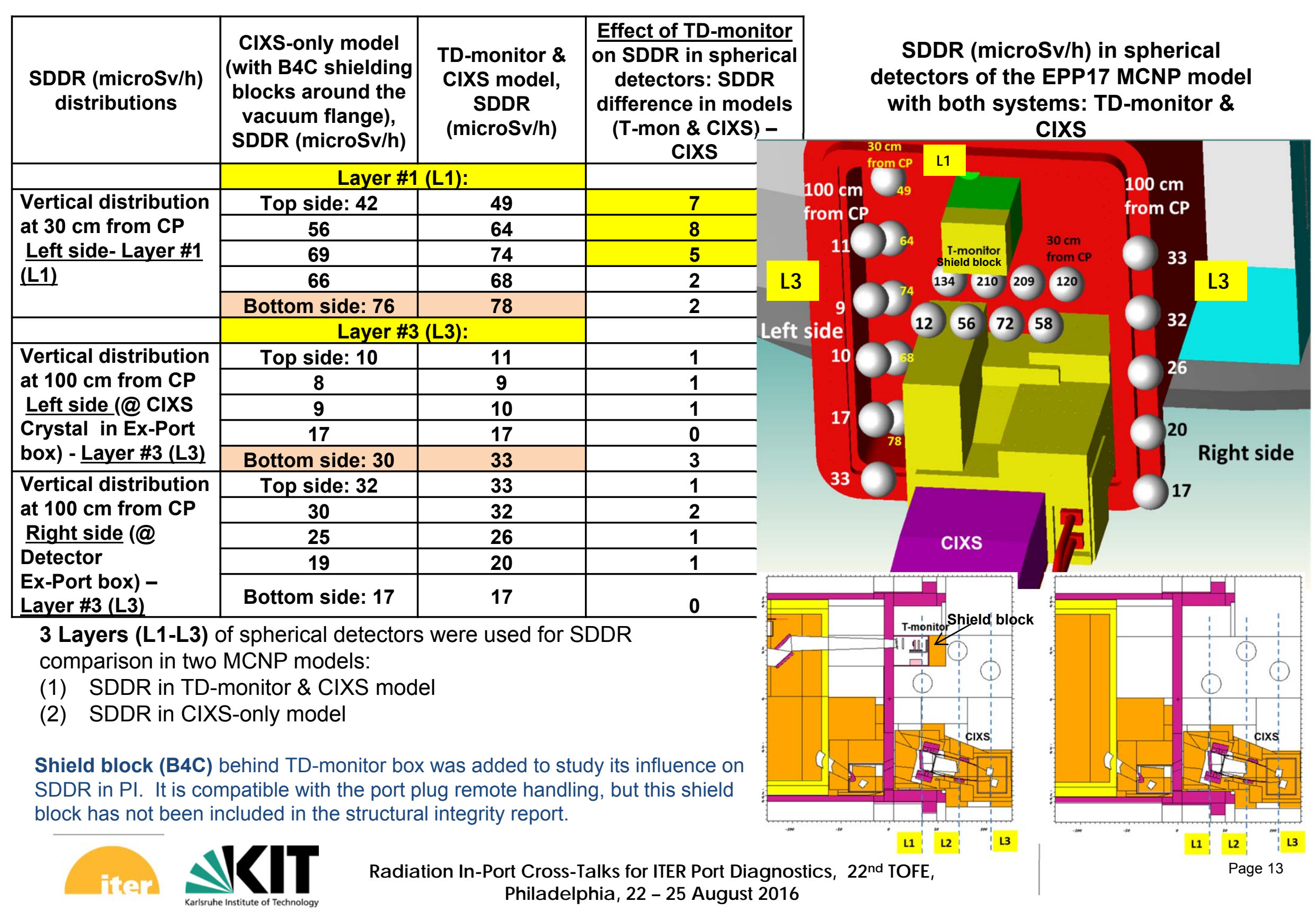




\section{SDDR horizontal distributions and effect of TD-monitor on SDDR}

Horizontal SDDR (microSv/h) distributions in spherical detectors of TD-monitor \& CIXS model

\begin{tabular}{|c|c|c|c|c|c|}
\hline Layer \# & $\begin{array}{c}\text { Detectors location in } \\
\text { horizontal distribution }\end{array}$ & Left & & & Right \\
\hline L1 & $\begin{array}{c}\text { Below the TD-monitor, } \\
\text { at 30cm from CP }\end{array}$ & 134 & 210 & 209 & 120 \\
\hline L2 & $\begin{array}{c}\text { Behind the TD-monitor, } \\
\text { at 66cm from CP }\end{array}$ & 27 & 59 & 78 & 69 \\
\hline L3 & $\begin{array}{c}\text { Far from TD-monitor, } \\
100 \mathrm{~cm} \text { from CP }\end{array}$ & 12 & 56 & 72 & 58 \\
\hline
\end{tabular}

Horizontal SDDR (microSv/h) distributions in detectors of CIXS-only model

\begin{tabular}{|c|c|c|c|c|c|}
\hline Layer \# & $\begin{array}{c}\text { Detectors location in } \\
\text { horizontal distribution }\end{array}$ & Left & & Right \\
\hline L1 & $\begin{array}{c}\text { Below the TD-monitor, } \\
\text { at 30cm from CP }\end{array}$ & 121 & 193 & 194 & 117 \\
\hline L2 & $\begin{array}{c}\text { Behind the TD-monitor, } \\
\text { at } 66 \text { cm from CP }\end{array}$ & 32 & 66 & 74 & 63 \\
\hline L3 & $\begin{array}{c}\text { Far from TD-monitor, } \\
100 \mathrm{~cm} \text { from CP }\end{array}$ & 11 & 56 & 67 & 55 \\
\hline
\end{tabular}

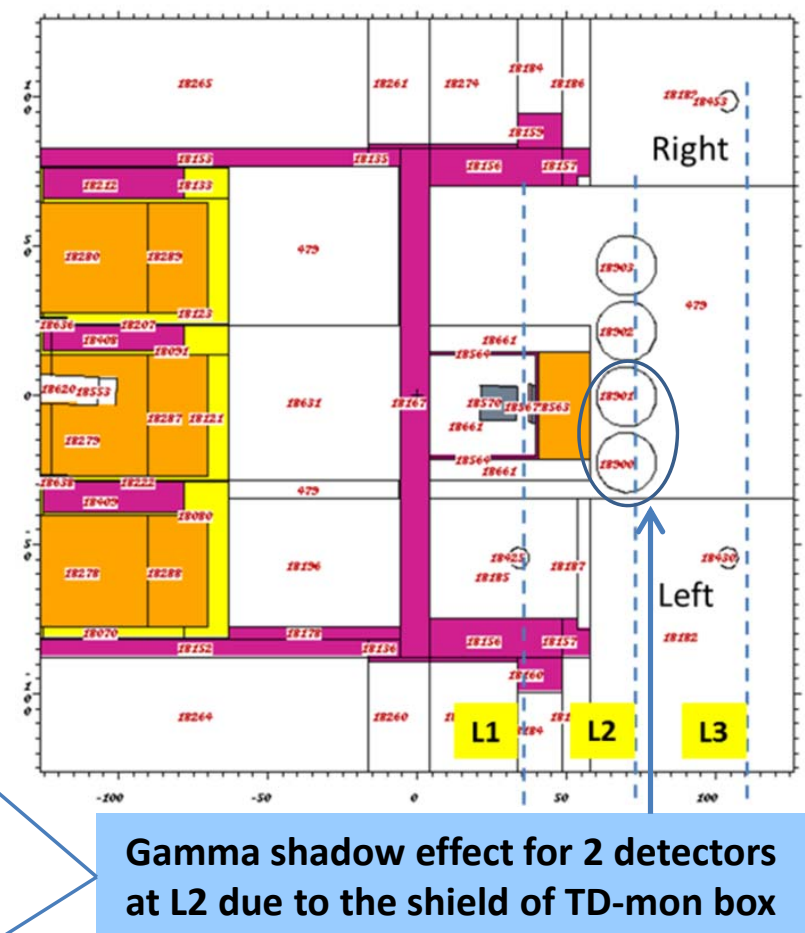

Effect of TD-monitor on SDDR in spherical detectors. Difference of SDDR

(microSv/h) in two models: (TD-mon \& CIXS model ) - CIXS-only model

\begin{tabular}{|c|c|c|c|c|c|}
\hline Layer \# & $\begin{array}{c}\text { Detectors location in } \\
\text { horizontal distribution }\end{array}$ & Left & & Right \\
\hline L1 & $\begin{array}{c}\text { Below the TD-monitor, } \\
\text { at 30cm from CP }\end{array}$ & 13 & 17 & 15 \\
\hline L2 & $\begin{array}{c}\text { Behind the TD-monitor, } \\
\text { at 66cm from CP }\end{array}$ & -5 & -7 & 4 & 6 \\
\hline L3 & $\begin{array}{c}\text { Far from TD-monitor, } \\
100 \mathrm{~cm} \text { from CP }\end{array}$ & 1 & 0 & 5 & 3 \\
\hline
\end{tabular}




\section{Summary and Recommendations}

- Neutronics analysis was performed in the MCNP Local model of EPP17 included only the apertures of two Diagnostics: TD-monitor and CIXS.

- The results include neutron and gamma fluxes and nuclear heating on 7 mirrors of the TD-monitor, neutron fluxes and SDDR estimated in spherical detectors and with 3D distributions in EPP17:

- Nuclear heating on mirrors is up to $0.77 \mathrm{~W} / \mathbf{c m}^{3}$ (cooling might be required).

- SDDR in spherical detectors at the bottom of TD-monitor shield box (at $30 \mathrm{~cm}$ from Closure Plate) reaches $210 \mathrm{microSv} / \mathrm{h}$, with a contribution of $17 \mathrm{microSv} / \mathrm{h}$ from TD-monitor.

- Shield block behind the TD-monitor contribute to a decrease on $7 \mathbf{m i c r o S v} / \mathbf{h}$ - gamma shadow effect.

- These are relative SDDR values of Local MCNP model. Final values request inclusion of all the tenants of EPP17 (TD-monitor, CIXS, Vis/IR system, and Divertor Thermography) - future task of EPP17 port plug integration, with inclusion of all the sorts of the gaps, radiation cross-talks between the ports, and environmental effects in global MCNP C-lite model.

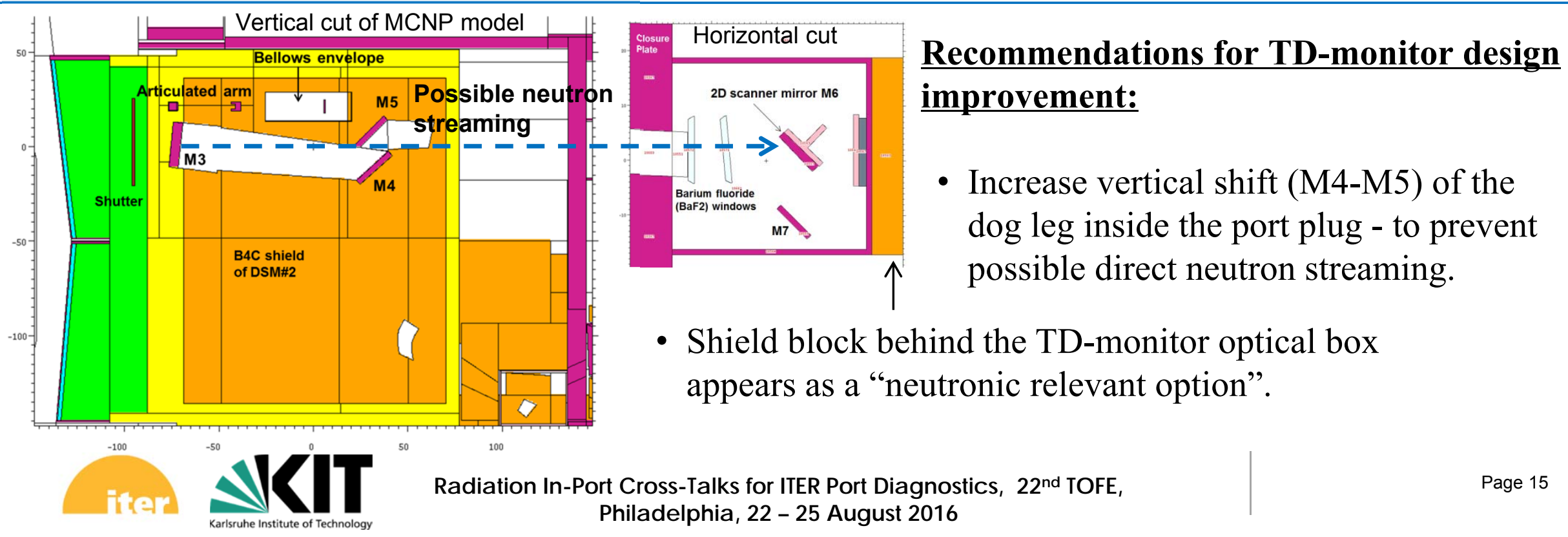




\section{SDDR map in model with both systems: TD-monitor \& CIXS}

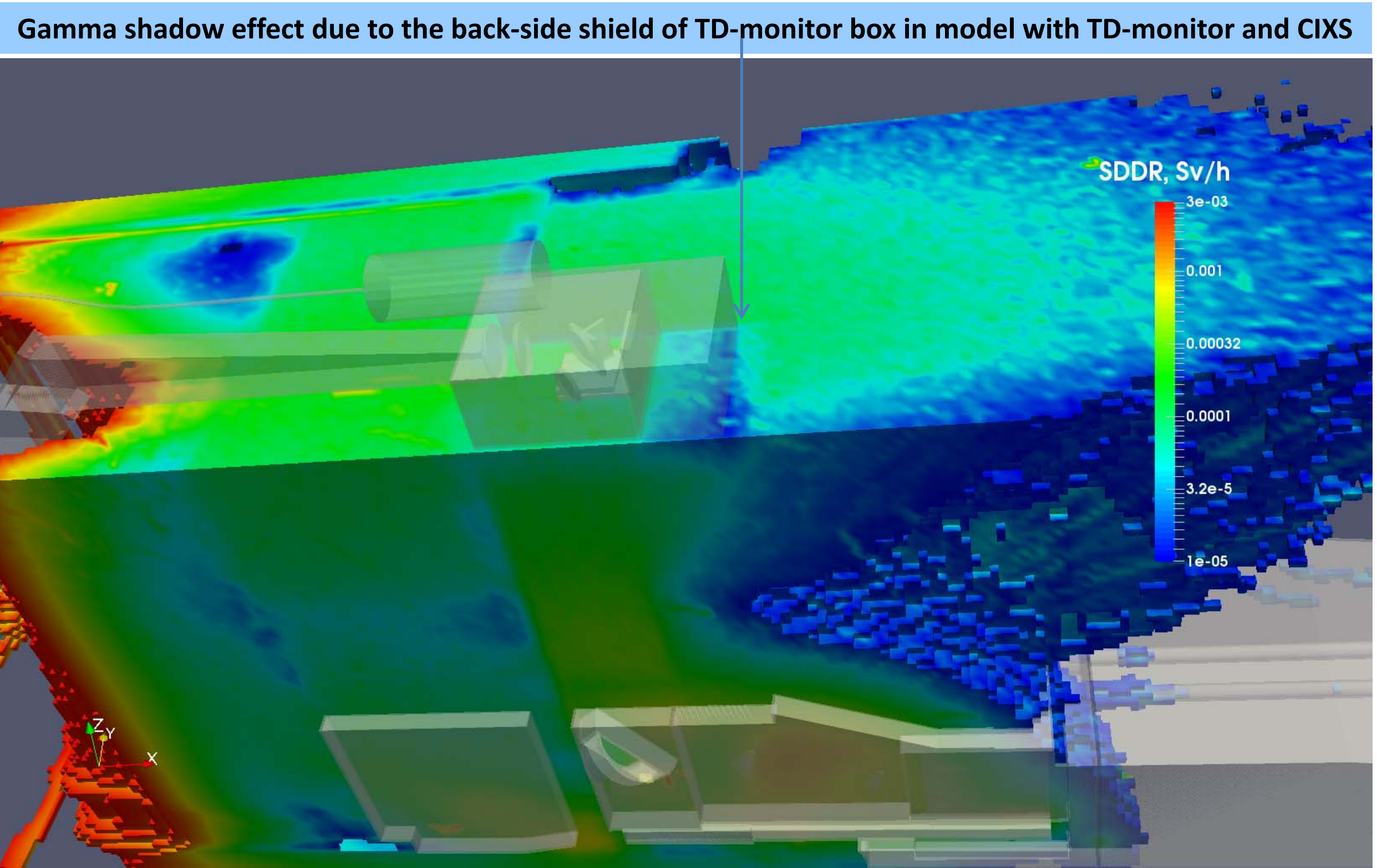




\section{SDDR map in the EPP17 model with CIXS system only}

\section{No shadow obsenved in PI of the MCNP model included only the CIXS system}

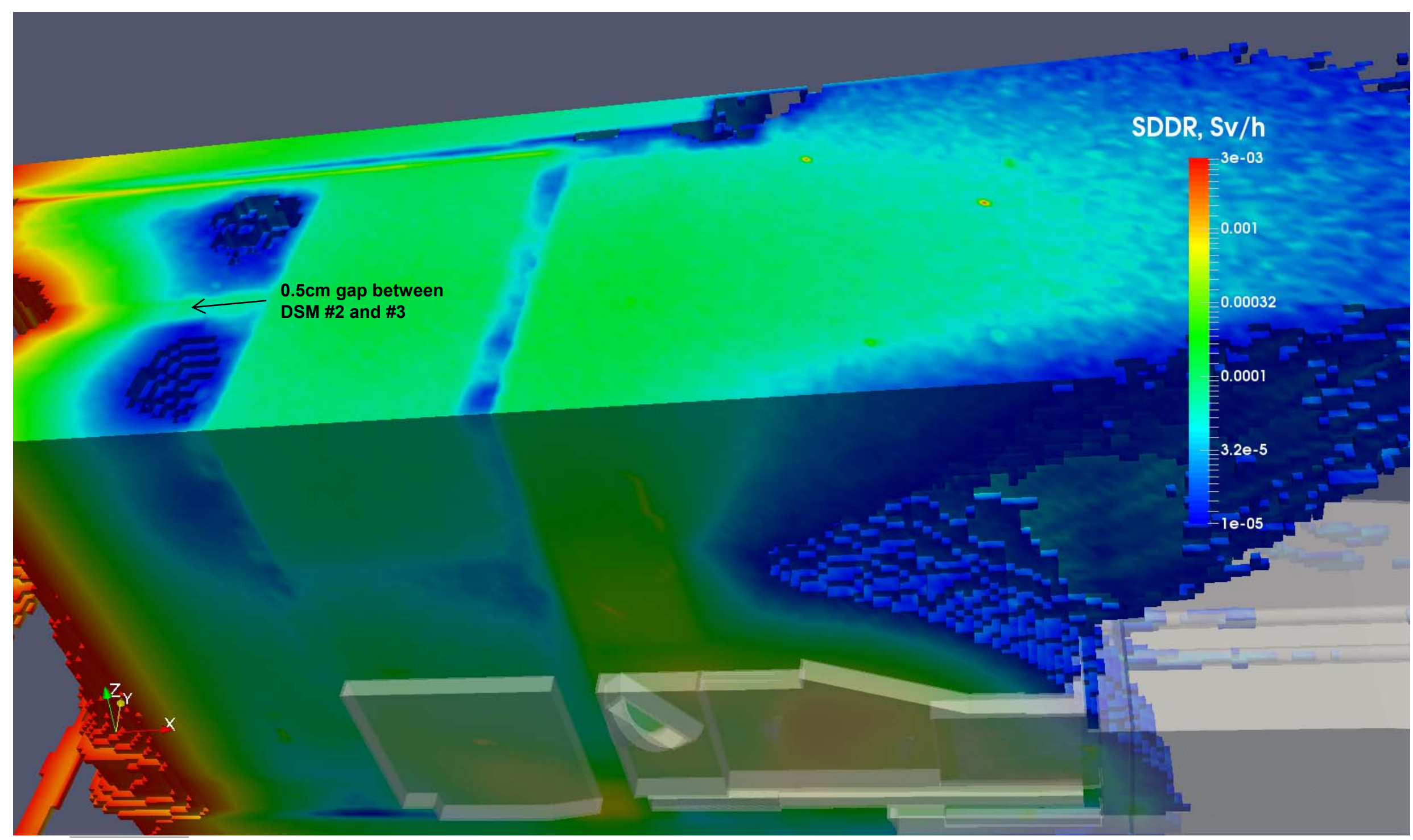




\section{Gamma shadow effect due to the shield of TD-monitor box}

Thresholded SDDR map (10 mic roSv/h - $100 \mathrm{microSv} / \mathrm{h}$ ) to illustrate gamma shadow effect due to the back-side shield of TD-monitor box in model with TD-monitor and CIXS

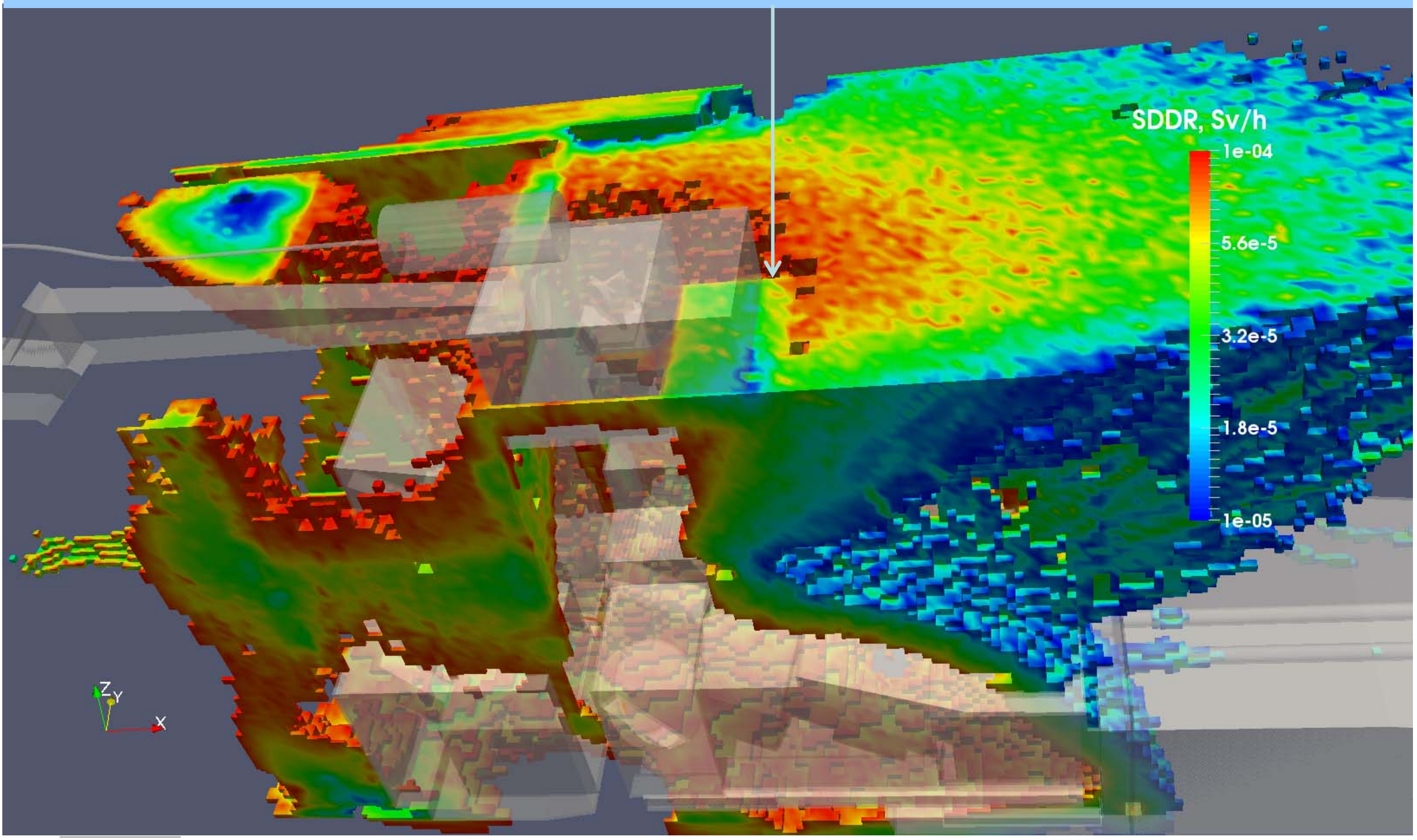




\section{In-port radiation cross-talks}

Example 2: Tangential Neutron Spectrometer (TNS) inside the EPP \#8 with 7 Diagnostics in C-lite v.2 


\section{Reduce (eliminate) radiation cross-talk from the Fast lon Loss Detector (FILD) to Tangential Neutron Spectrometer (TNS) in EPP \#8}

Neutron spectra calculation in detectors of Tangential Neutron Spectrometer (TNS) inside the EPP8 with 7 diagnostic systems in C-lite v.2

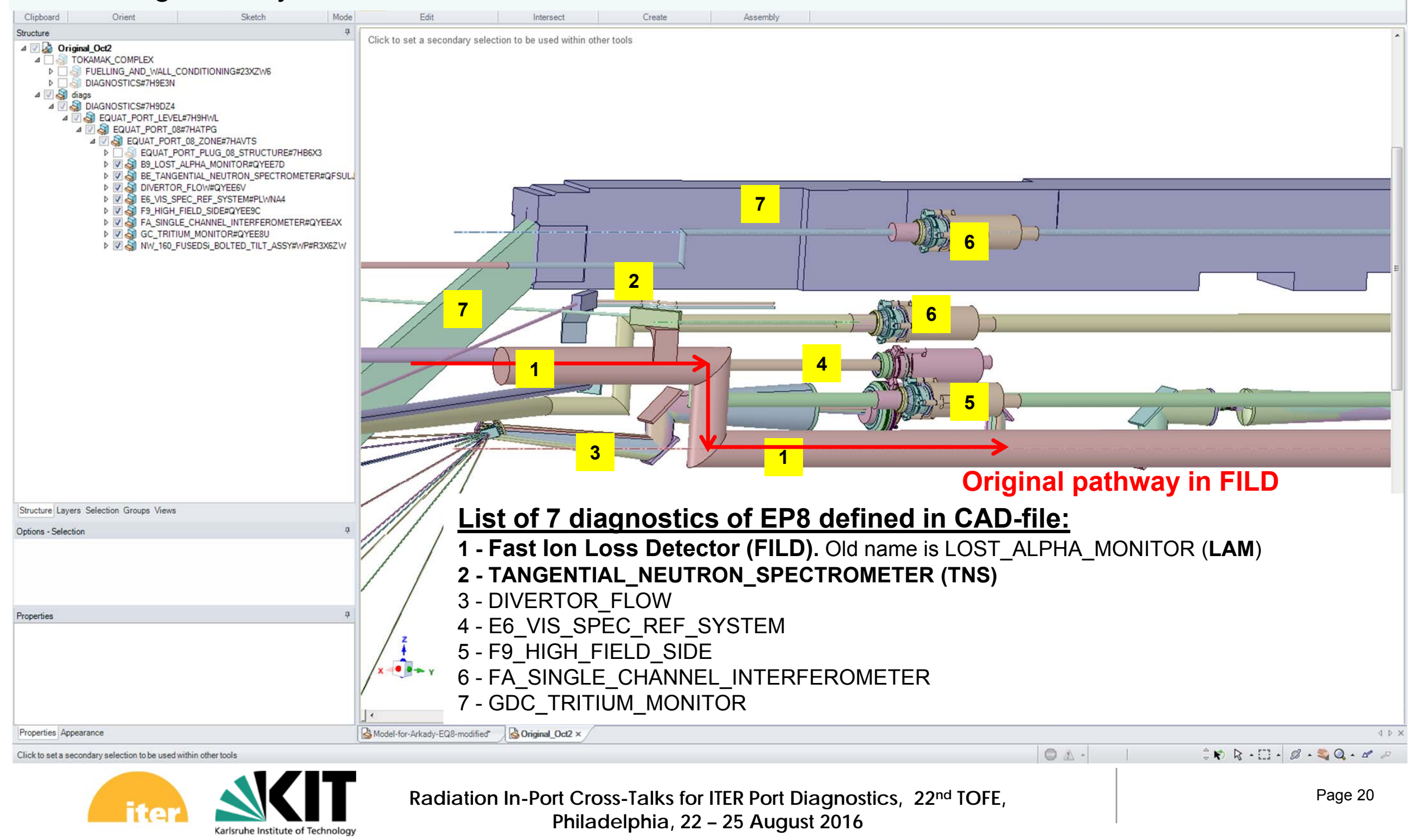


Filled LAM with the EQ8 shield material (B4C), numerical results are available:

https://user.iter.org/?uid=S36B22 with Excel file with neutron spectra in TNS of the EQ8 without Lost Alpha Monitor (S36B22)

Neutron streaming in FILD (LAM) path: \begin{tabular}{|l|l|}
$\begin{array}{l}\text { Peak factor (F_14MeV_per } \\
\text { lethargy/F_sum E>10MeV)= } \quad 4.4705 E+00\end{array}$ & Ratio uncollided/total = 2.0488E-04 \\
\hline
\end{tabular}

If FILD (LAM) is filled with shield - then peak factor is increased by two times (8.2), but ratio of uncollided flux to total flux is decreased by two times $(1.08 \mathrm{e}-4)$. This is due to stronger moderation of neutrons by the shield:

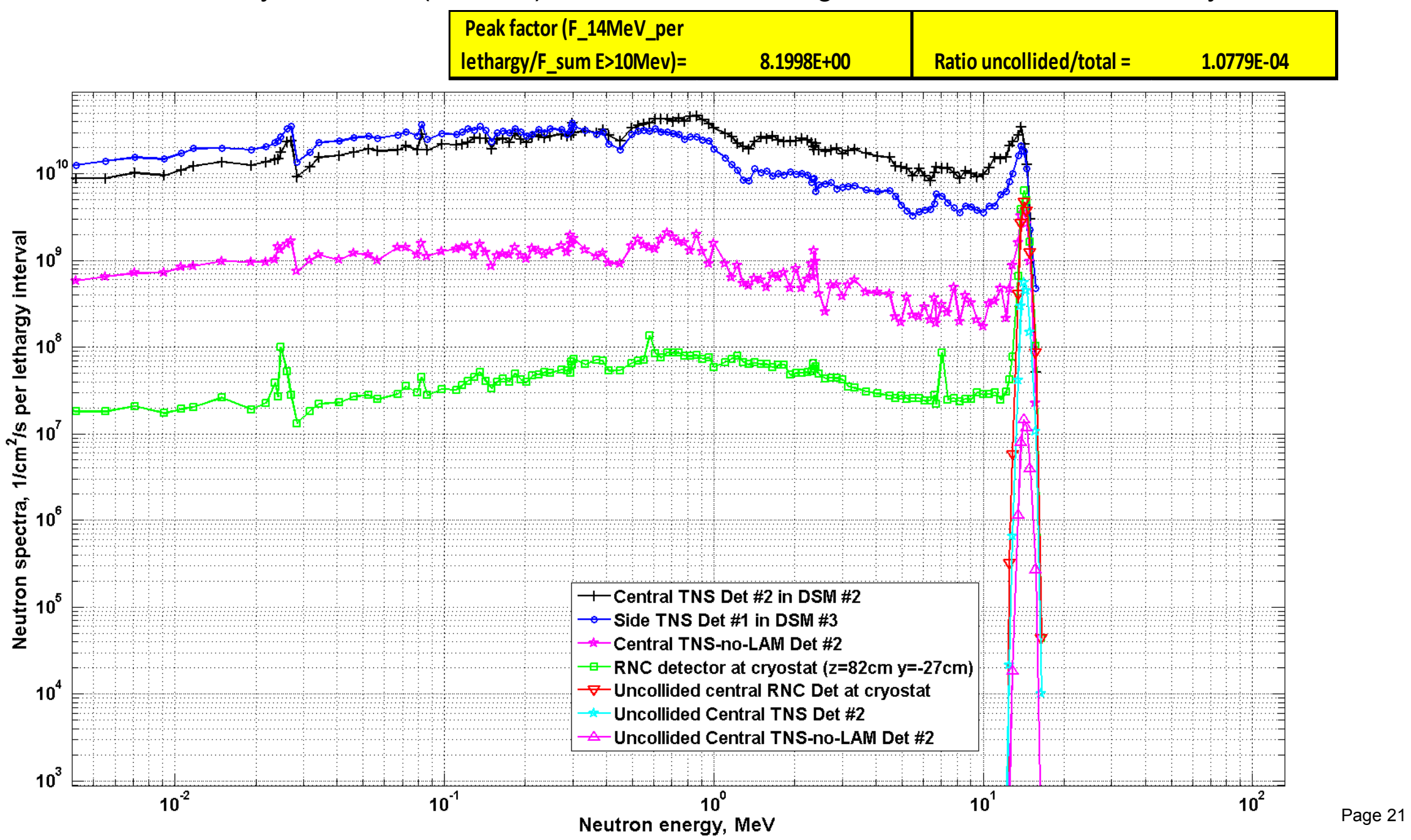



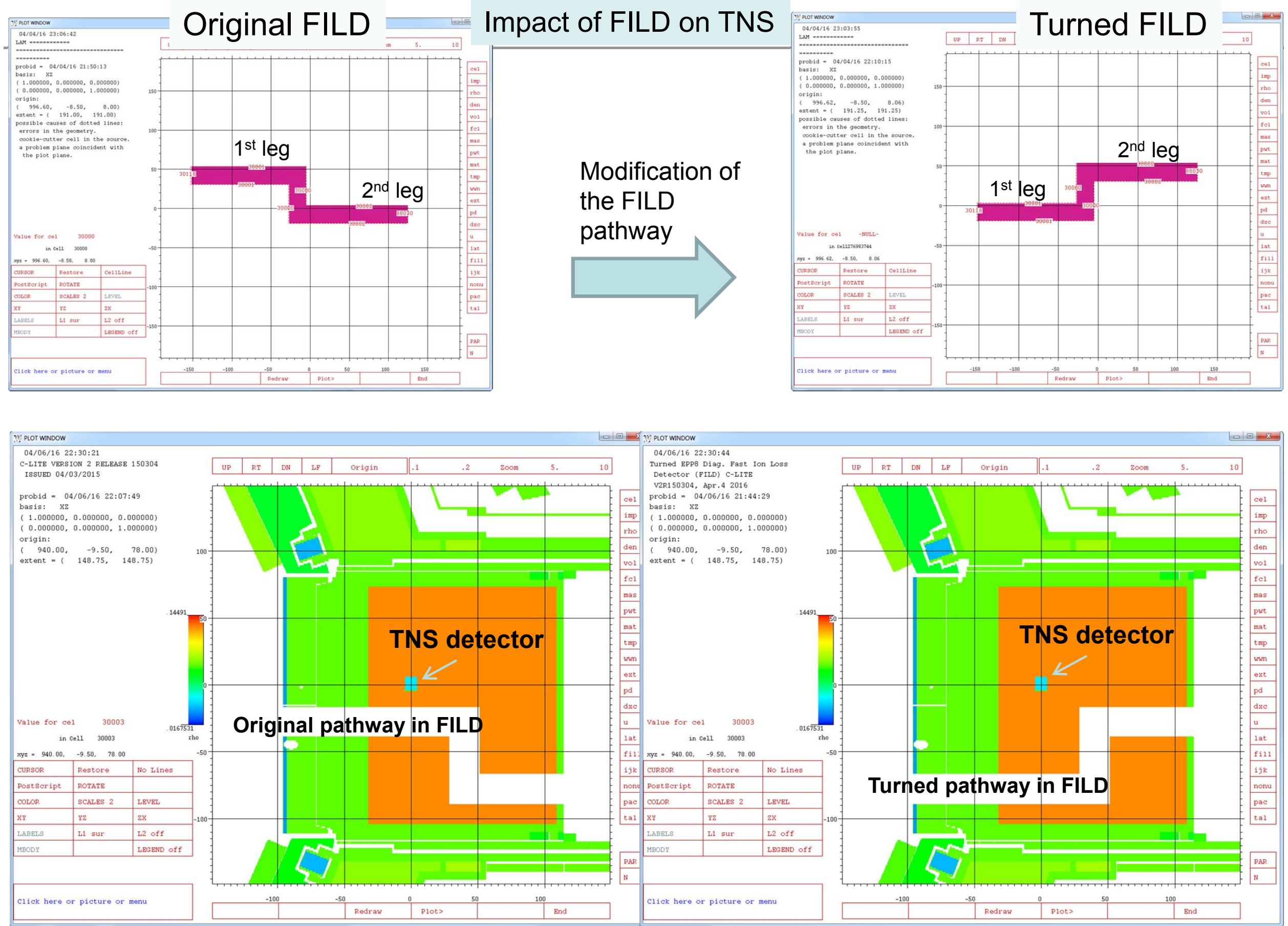
MCNP neutron spectra calculations in TNS detectors of EPP \#8 in C-lite V2 with turned upside-down LAM (FILD)

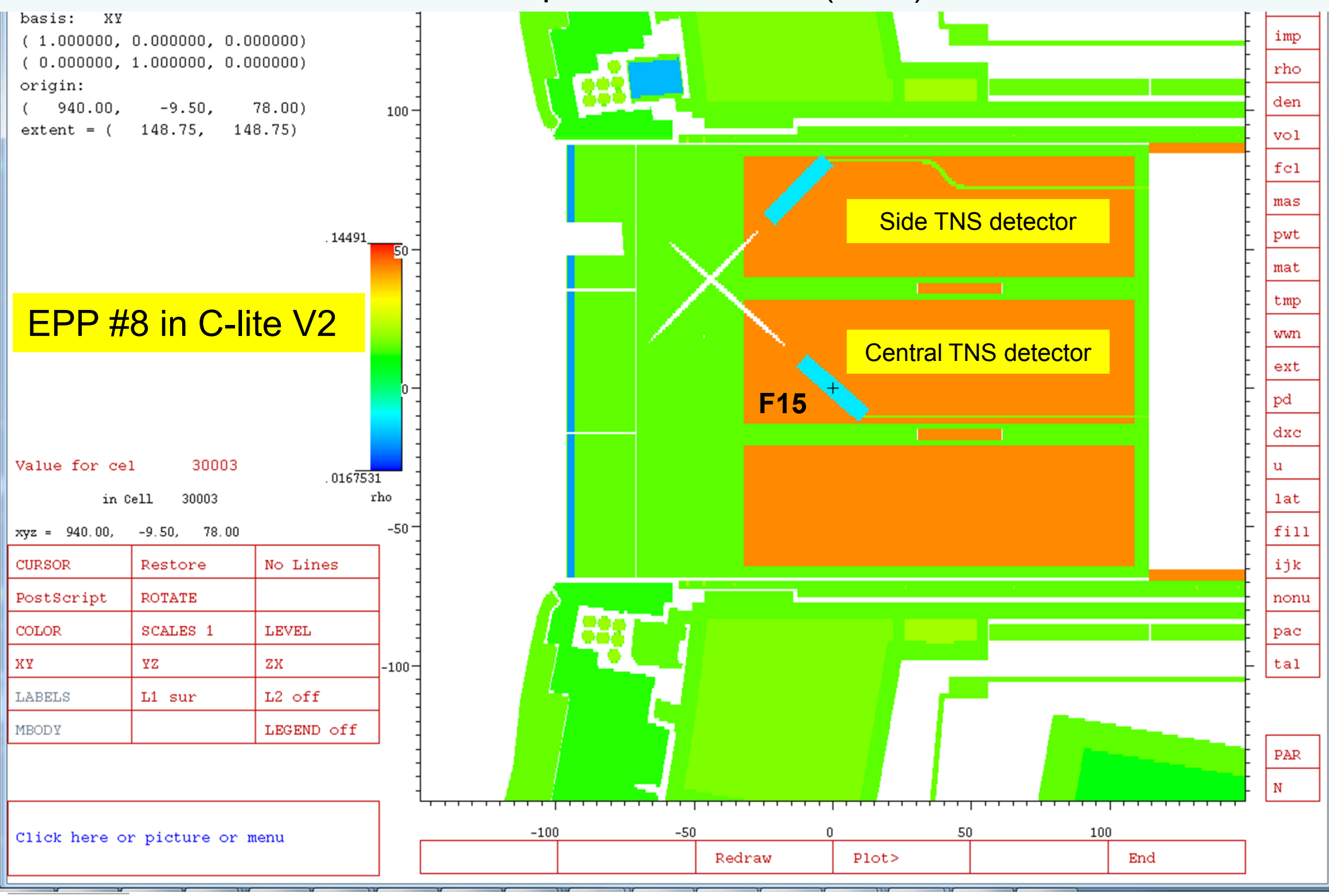

Radiation In-Port Cross-Talks for ITER Port Diagnostics, 22nd TOFE, Philadelphia, 22 - 25 August 2016 

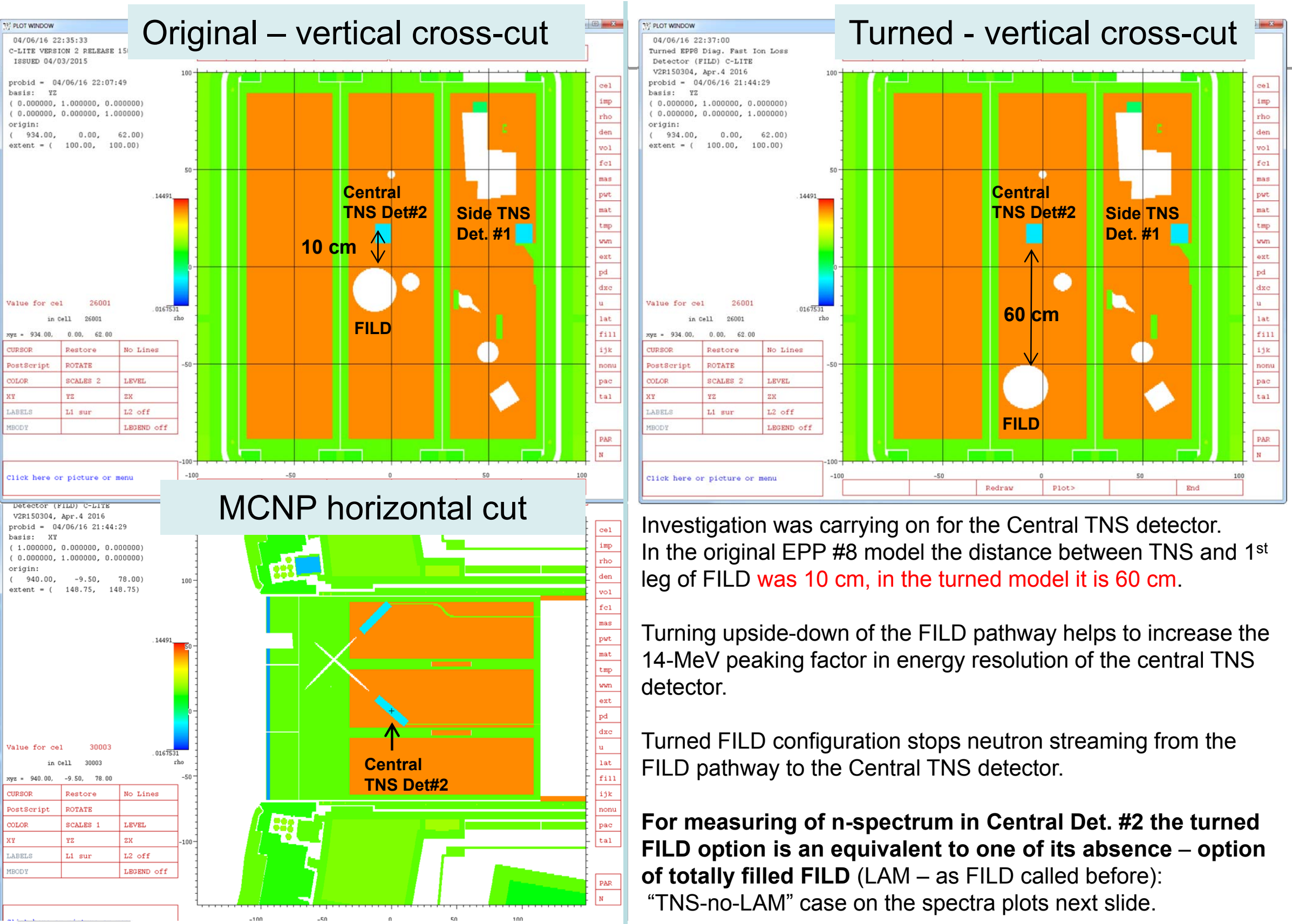

Investigation was carrying on for the Central TNS detector.

In the original EPP \#8 model the distance between TNS and $1^{\text {st }}$ leg of FILD was $10 \mathrm{~cm}$, in the turned model it is $60 \mathrm{~cm}$.

Turning upside-down of the FILD pathway helps to increase the 14-MeV peaking factor in energy resolution of the central TNS detector.

Turned FILD configuration stops neutron streaming from the FILD pathway to the Central TNS detector.

For measuring of $n$-spectrum in Central Det. \#2 the turned FILD option is an equivalent to one of its absence - option of totally filled FILD (LAM - as FILD called before):

"TNS-no-LAM" case on the spectra plots next slide. 


\section{Eliminating cross-talks between TNS and LAM (FILD)}

In Central TNS Detector \#2 the neutron spectra are coincided for two cases:

1) Totally removed LAM (FILD)

2) Turned upside-down LAM (FILD)

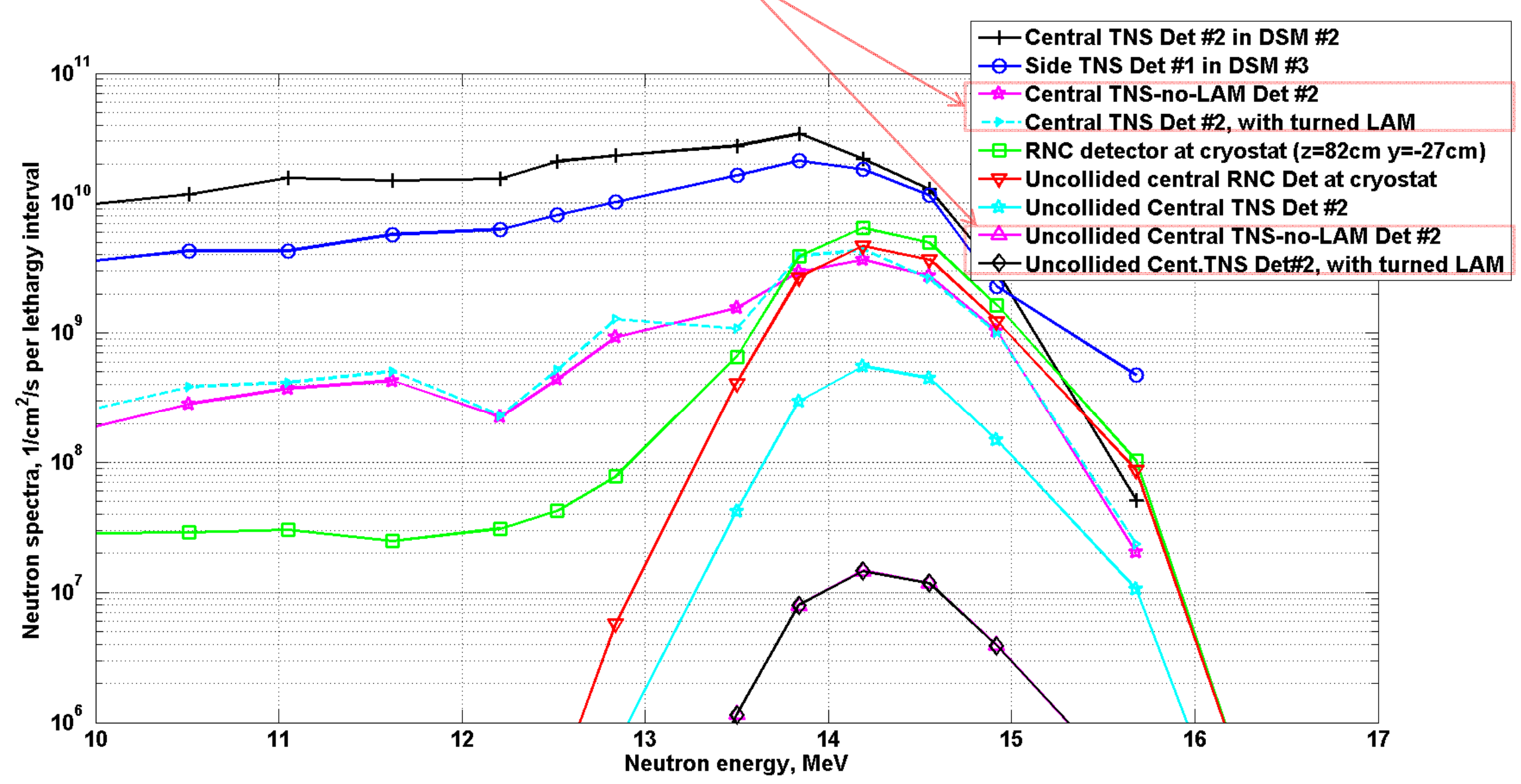

Radiation In-Port Cross-Talks for ITER Port Diagnostics, 22nd TOF,

Philadelphia, 22 - 25 August 2016 


\section{In-port radiation cross-talks}

Example 3: Shutter and the main Diagnostic path of the Charge eXchange Recombination Spectroscopy (CXRS) in UPP \#3 
3 Cases of MCNP neutronic models considered in analysis of Charge eXchange Recombination Spectroscopy (CXRS) in UPP\#3:

- Case \#1 of UPP\#3 with CXRS and GDC;

- Case \#2 of UPP\#3 with CXRS only;

- Case \#3 modified GUPP FDR 2013, with inclusion of single labyrinth in bottom gap

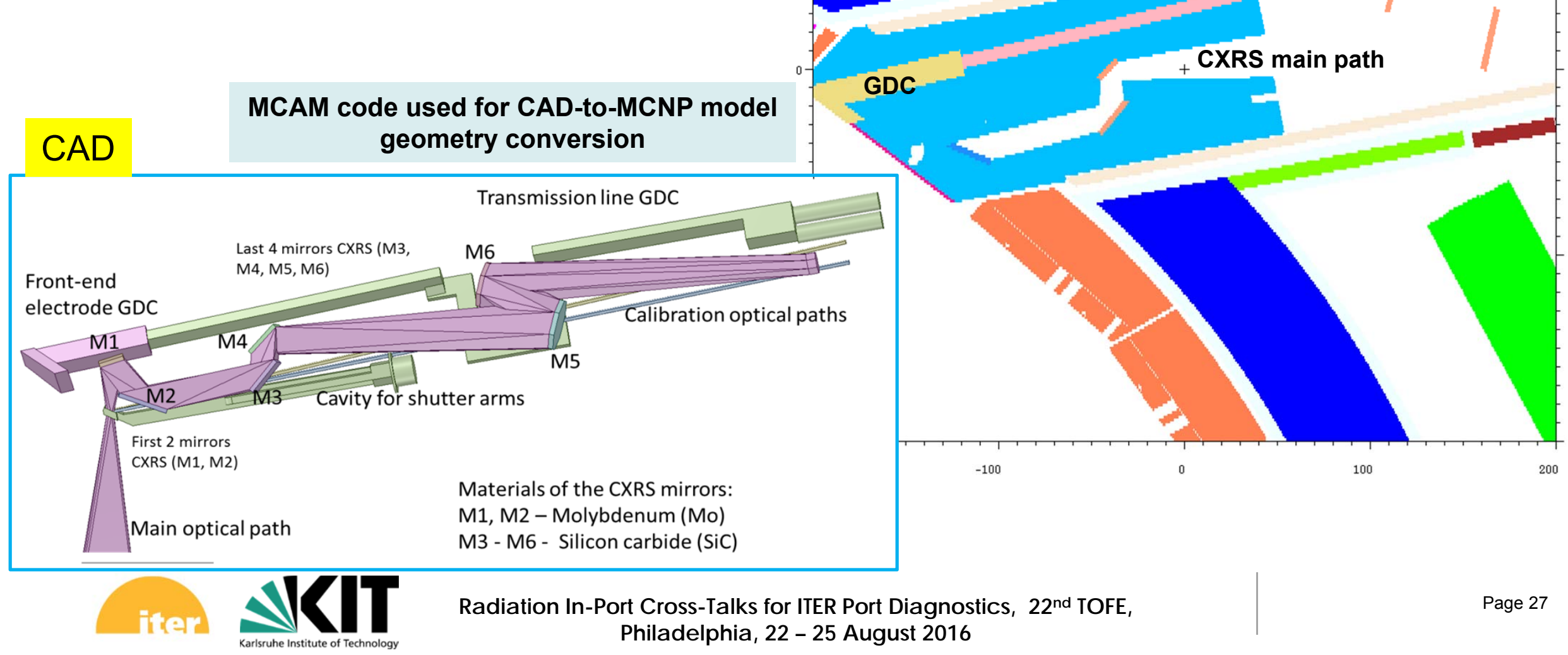




\section{Detailed neutronics results for the CXRS mirrors}

Materials of the CXRS mirrors: M1, M2 - Molybdenum (Mo)

M3 - M6 - Silicon carbide (SiC)

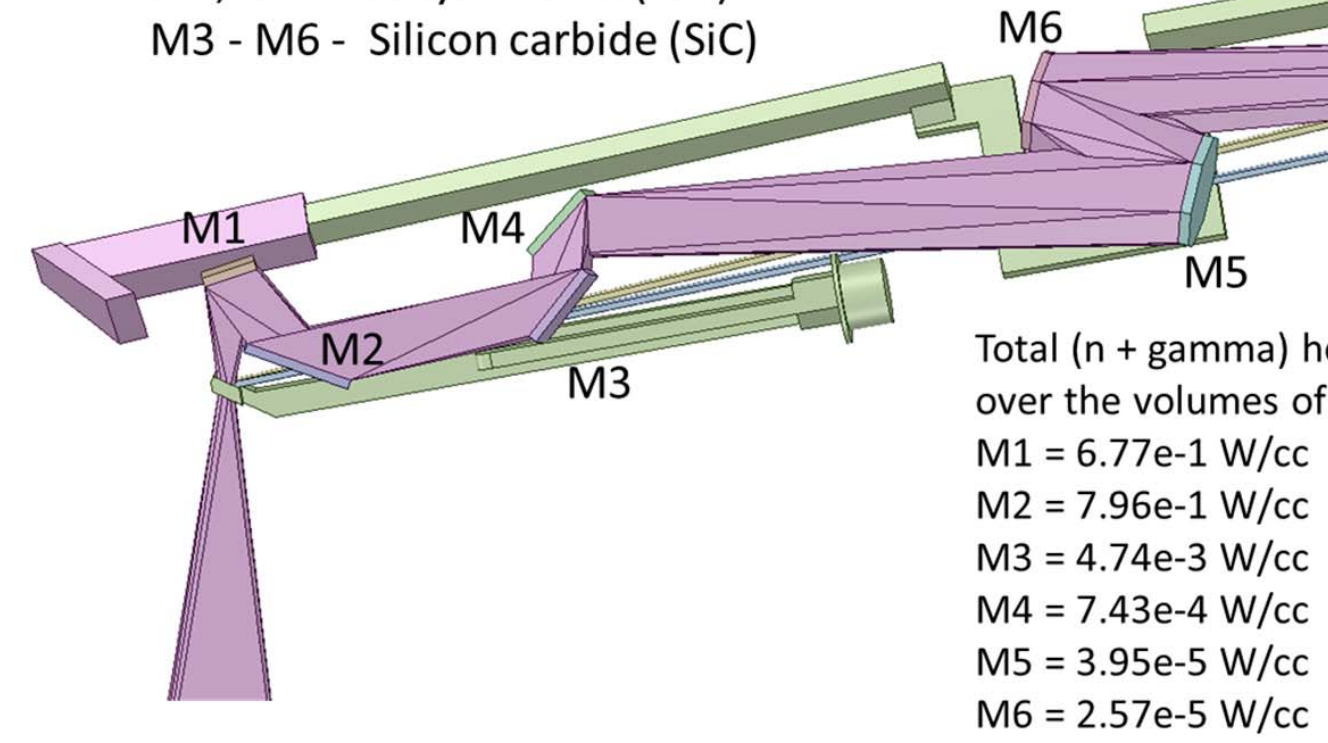

\begin{tabular}{|c|c|c|c|c|c|c|c|c|}
\hline MCNP cell number & $\begin{array}{l}\text { Mirror } \\
\text { number }\end{array}$ & Material & $\begin{array}{c}\text { Volume, } \\
\text { cm3 }\end{array}$ & $\begin{array}{c}\text { Neutron flux, } \\
\mathrm{n} / \mathrm{cm} 2 / \mathrm{s}\end{array}$ & $\begin{array}{c}\text { Gamma flux, } \\
\text { gamma/ cm2/s }\end{array}$ & $\begin{array}{c}\text { Neutron } \\
\text { heating, } \\
\text { W/cm3 }\end{array}$ & $\begin{array}{c}\text { Gamma } \\
\text { heating, } \\
\text { W/cm3 }\end{array}$ & $\begin{array}{l}\text { Total }(\mathrm{n}+\mathrm{gamma}) \\
\text { heating, } \mathrm{W} / \mathrm{cm} 3\end{array}$ \\
\hline Cell 17500 & M1 & Molybdenum (Mo) & 469.8000 & $2.50 \mathrm{E}+13$ & $1.03 E+13$ & $1.48 \mathrm{E}-02$ & $6.62 \mathrm{E}-01$ & 6.77E-01 \\
\hline Cell 17512 & $\mathrm{M} 2$ & Molybdenum (Mo) & 945.0000 & $3.04 \mathrm{E}+13$ & $1.20 E+13$ & 1.79E-02 & $7.78 \mathrm{E}-01$ & $7.96 \mathrm{E}-01$ \\
\hline Cell 17502 & M3 & Silicon carbide (SiC) & 907.5000 & $7.24 \mathrm{E}+11$ & $2.89 \mathrm{E}+11$ & $5.89 \mathrm{E}-04$ & 4.15E-03 & $4.74 \mathrm{E}-03$ \\
\hline Cell 17530 & M4 & Silicon carbide (SiC) & 1061.1000 & $1.40 \mathrm{E}+11$ & $5.03 E+10$ & 5.87E-05 & $6.84 \mathrm{E}-04$ & $7.43 \mathrm{E}-04$ \\
\hline Cell 17529 & M5 & Silicon carbide (SiC) & 2748.0950 & $7.31 E+09$ & $2.91 \mathrm{E}+09$ & 8.29E-06 & $3.13 \mathrm{E}-05$ & $3.95 \mathrm{E}-05$ \\
\hline
\end{tabular}

For the interval of the MCNP statistical uncertainty (5\%), the neutron and photon fluxes averaged for the 6 mirrors are the same for the UPP-CXRS with or without GDC. 


\section{Total neutron flux (n/cm2/s) mapped over UPP with CXRS and GDC}

4 neutron streaming pathways in Case \#1 of UPP-CXRS with GDC:
1 - Gaps all-round the UPP

2 - CXRS shutter

3 - CXRS main optical path

4- GDC electrode

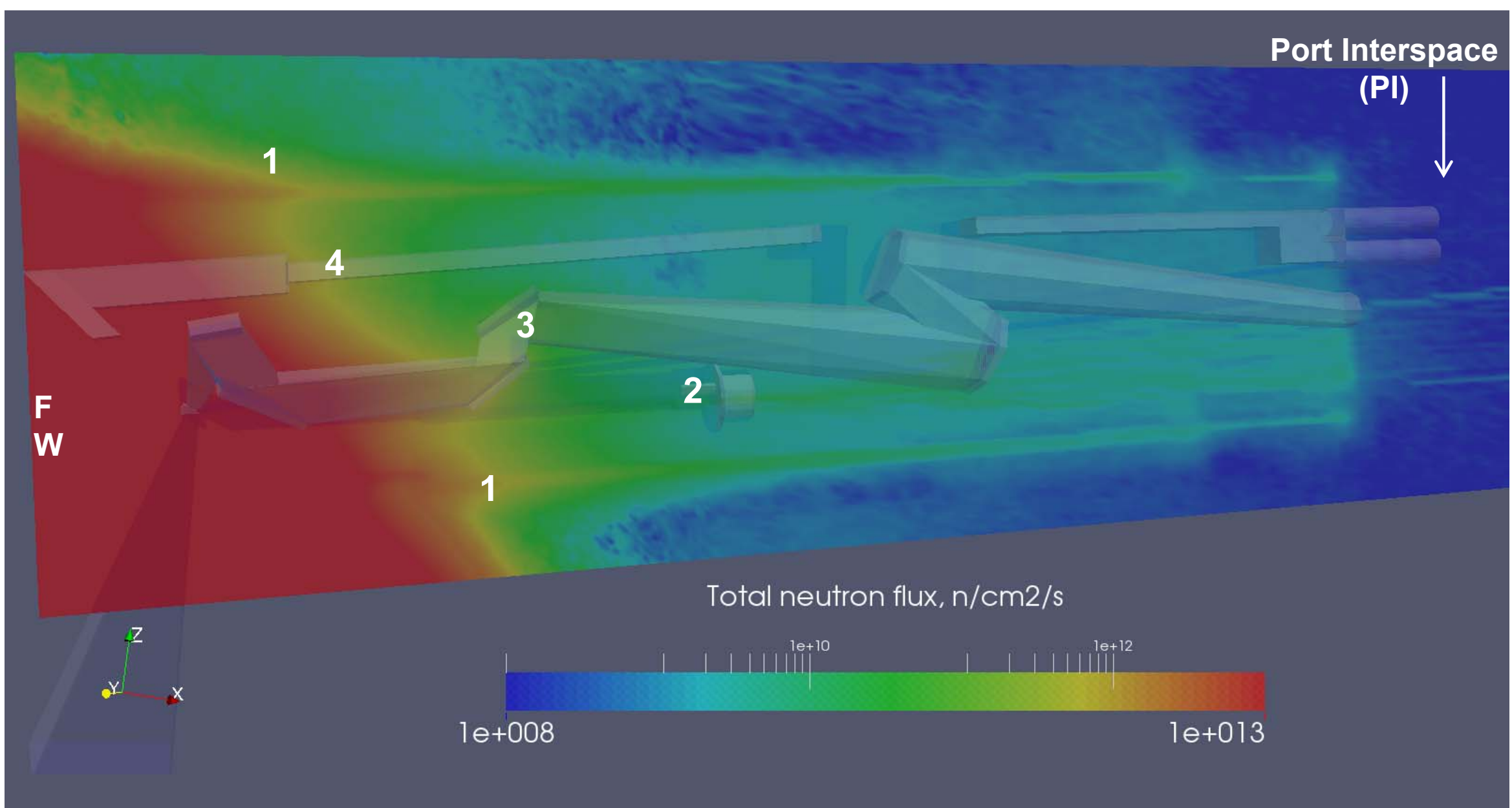




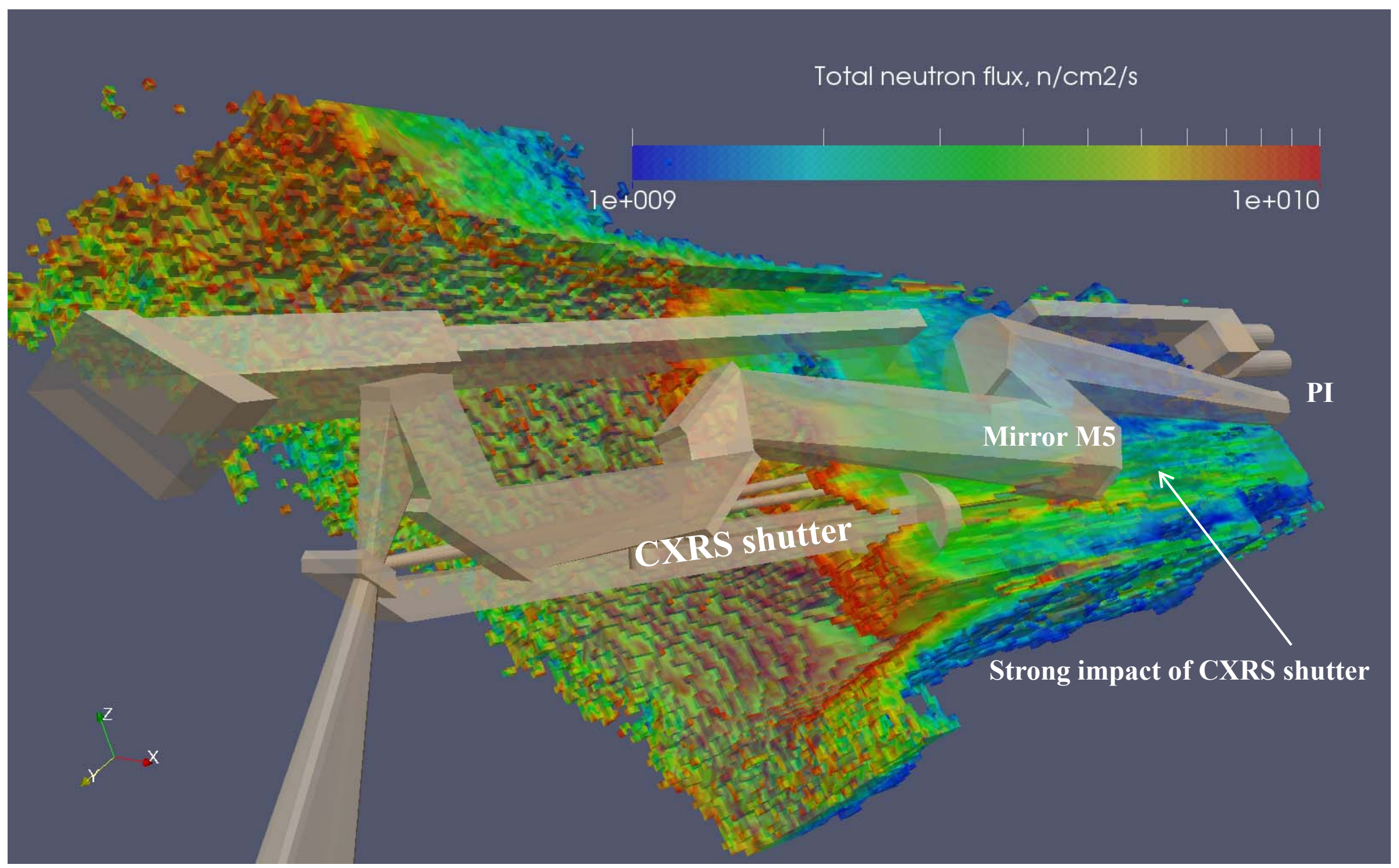




\section{Case \#1:}

UPP-CXRS with GDC 4 pathways of neutron streaming :

1 - Gaps all-round the UPP

2 - CXRS shutter

3 - CXRS main optical path

4 - GDC electrode

Neutron pathway analysis:

Case \#1 vs. Case \#2:

Case \#2:

UPP-CXRS except GDC 3 pathways of neutron streaming :

1 - Gaps all-round the UPP 2 - CXRS shutter

3 - CXRS main optical path

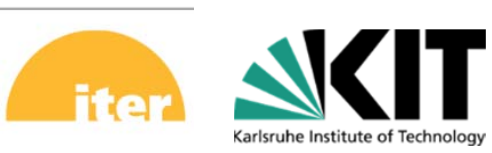

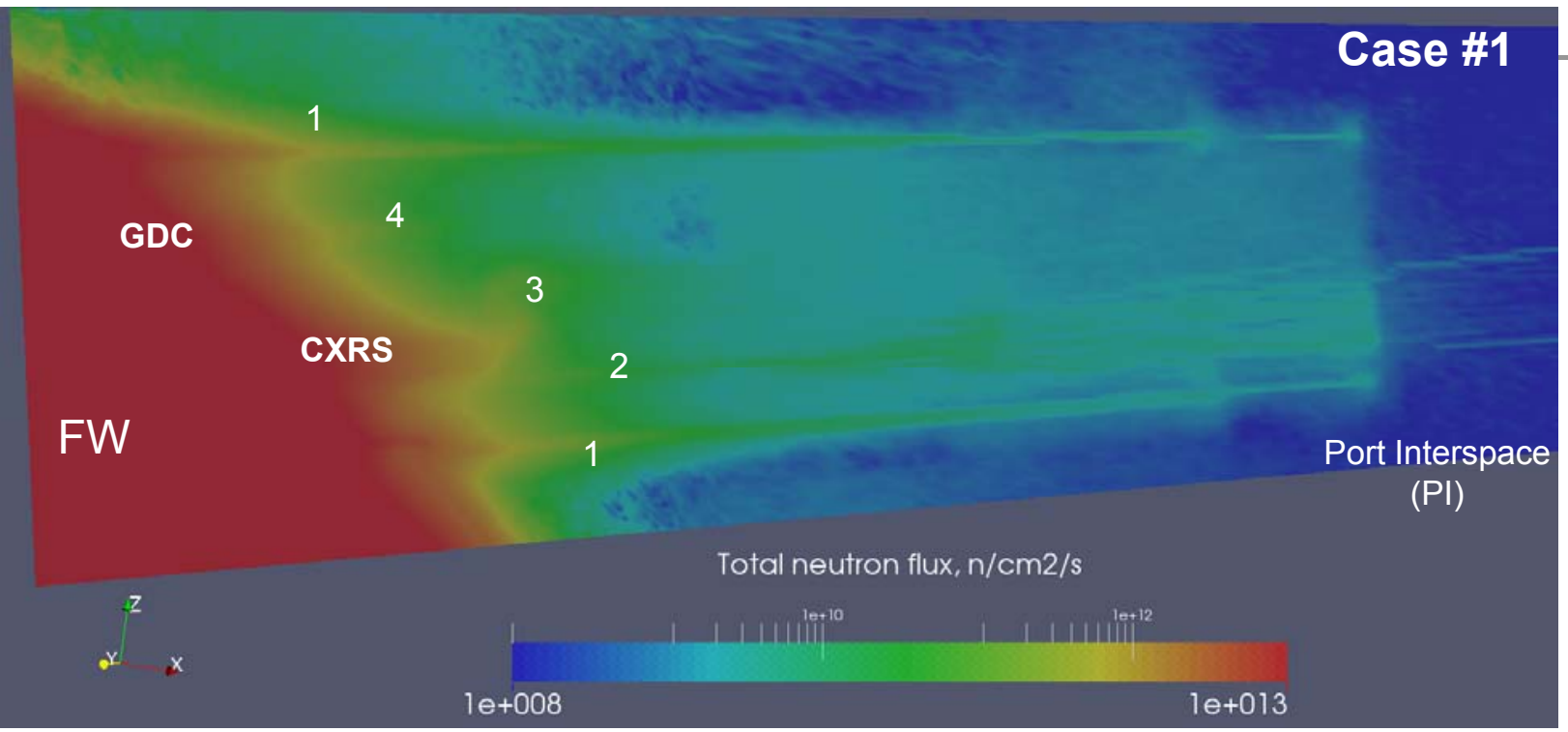

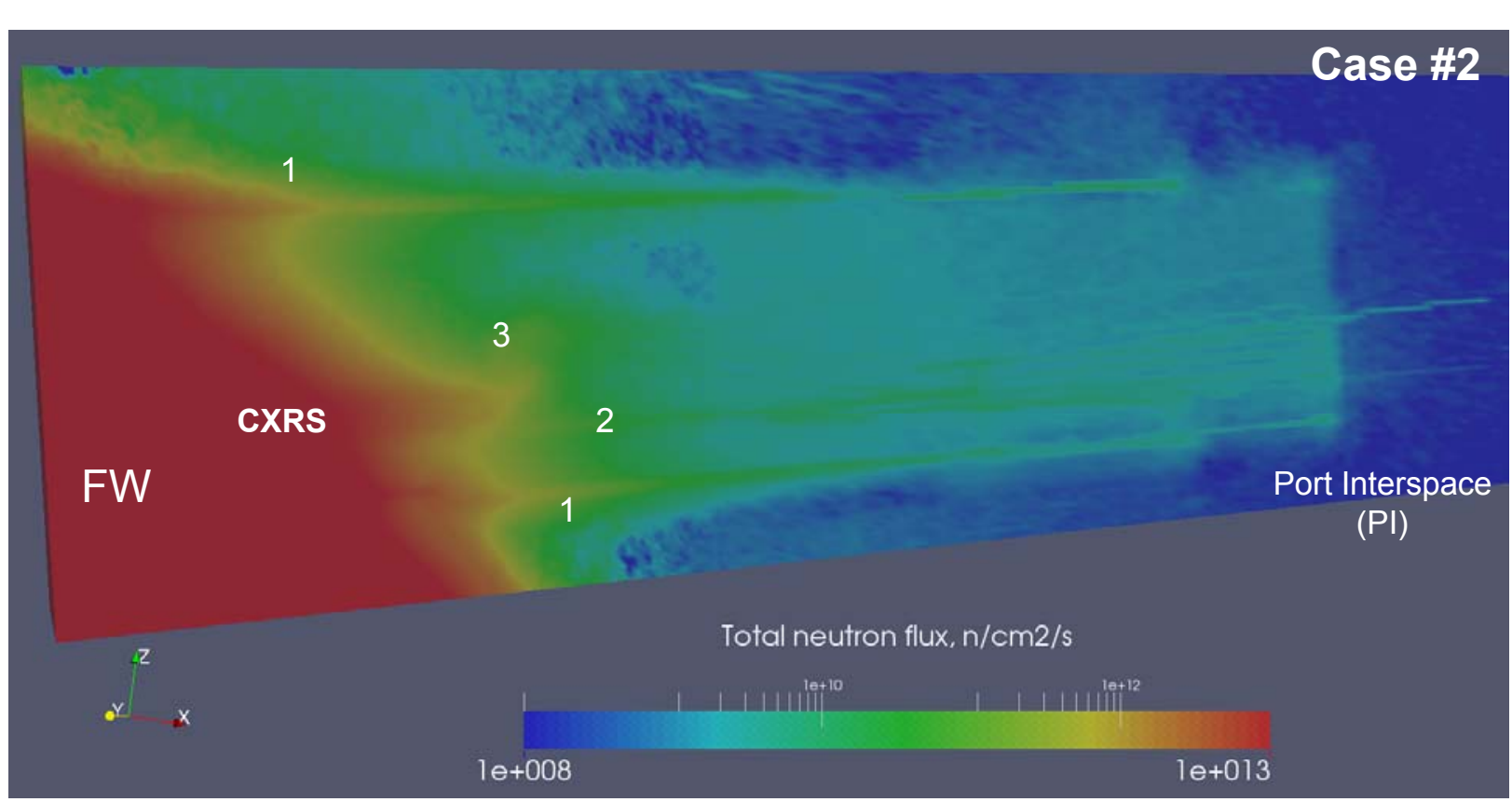

Radiation In-Port Cross-Talks for ITER Port Diagnostics, 22 ${ }^{\text {nd }}$ TOF, Philadelphia, 22 - 25 August 2016 


\section{Case 1:}

UPP-CXRS with GDC 4 pathways of neutron streaming :

1 - Gaps all-round the UPP 2 - CXRS shutter

3 - CXRS main optical path

4 - GDC electrode

Neutron pathway analysis:

Case \#1 vs. Case \#3:

Case 3:

Generic UPP

1 pathway of neutron

streaming :

1 - Gaps all-round the GUPP
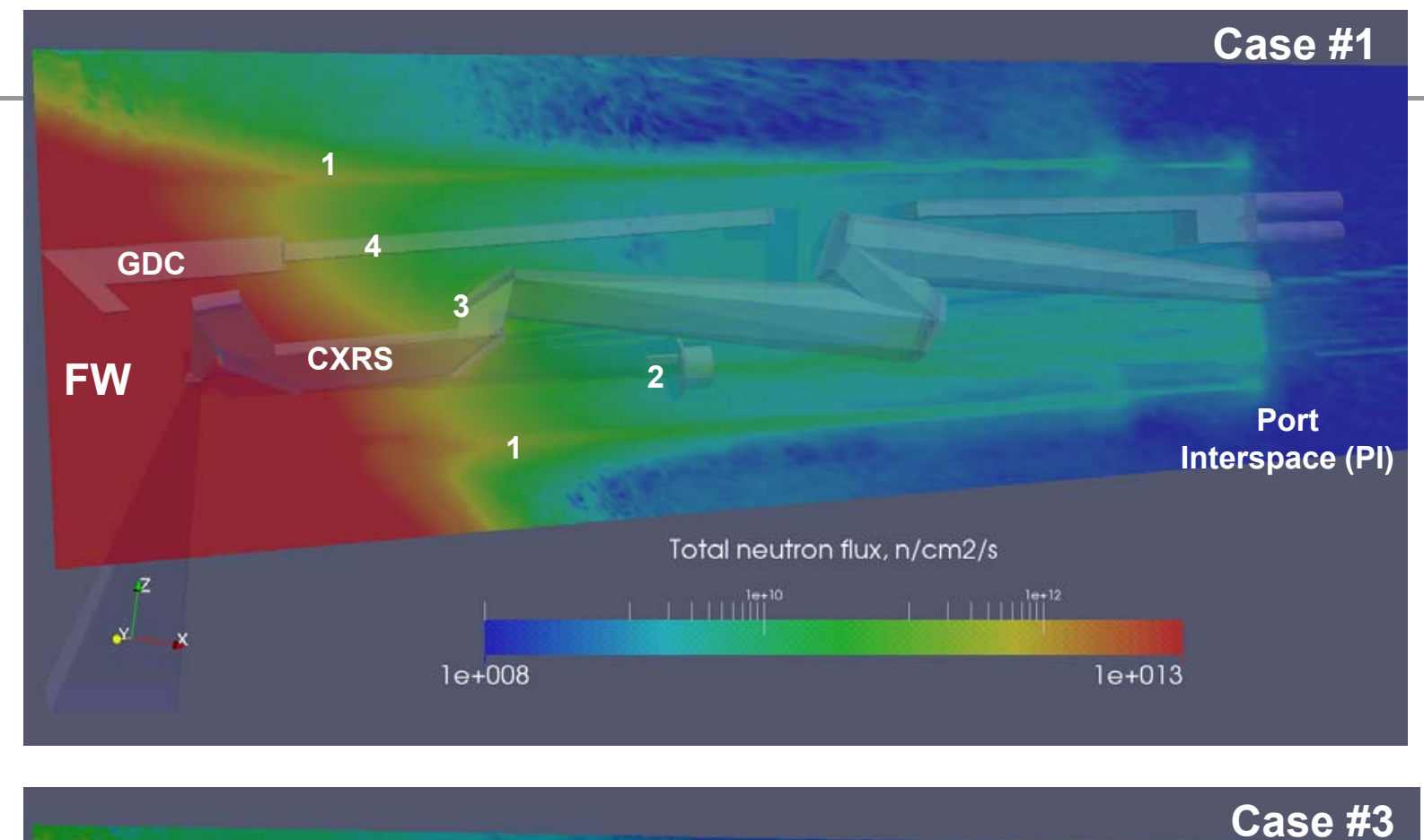

1

\section{GUPP}

FW

Total neutron flux, $\mathrm{n} / \mathrm{cm} 2 / \mathrm{s}$ 
UPP interspace control volumes F3 \& F4

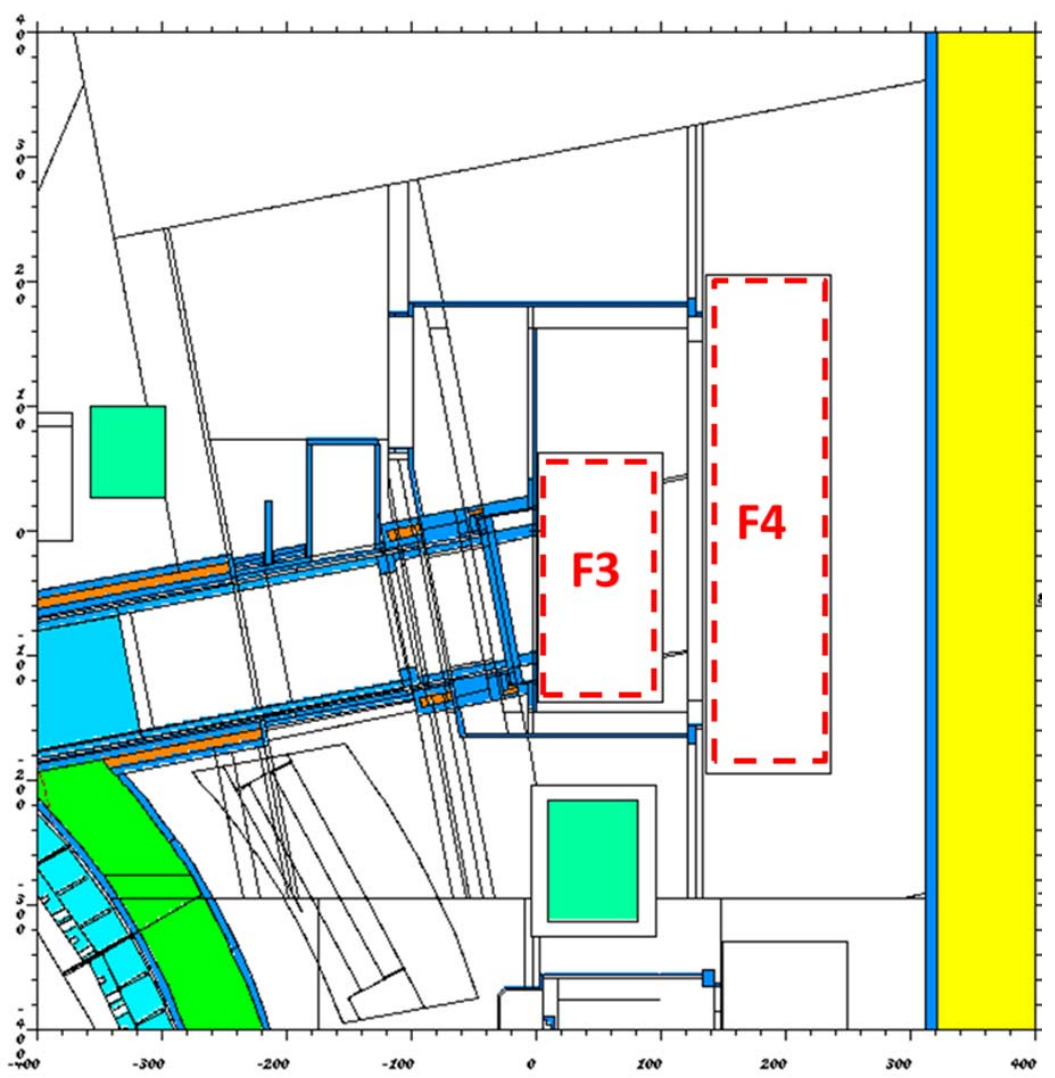

\begin{tabular}{|c|c|c|}
\hline $\begin{array}{c}\text { Case 1: UPP-CXRS with } \\
\text { GDC }\end{array}$ & $\begin{array}{c}\text { Neutron flux, } \\
\mathrm{n} / \mathrm{cm} 2 / \mathrm{s}\end{array}$ & $\begin{array}{c}\text { Gamma flux, } \\
\text { gamma/cm2/s }\end{array}$ \\
\hline F3 & $9.48 \mathrm{E}+07$ & $1.35 \mathrm{E}+07$ \\
\hline F4 & $6.52 \mathrm{E}+07$ & $9.42 \mathrm{E}+06$ \\
\hline
\end{tabular}

\begin{tabular}{|c|c|c|}
\hline $\begin{array}{c}\text { Case 2: UPP-CXRS } \\
\text { except GDC }\end{array}$ & $\begin{array}{c}\text { Neutron flux, } \\
\mathrm{n} / \mathrm{cm} 2 / \mathrm{s}\end{array}$ & $\begin{array}{c}\text { Gamma flux, } \\
\text { gamma/cm2/s }\end{array}$ \\
\hline F3 & $9.65 \mathrm{E}+07$ & $1.15 \mathrm{E}+07$ \\
\hline F4 & $6.64 \mathrm{E}+07$ & $8.64 \mathrm{E}+06$ \\
\hline
\end{tabular}

\begin{tabular}{|c|c|c|}
\hline Case 3: Generic UPP & $\begin{array}{c}\text { Neutron flux, } \\
\mathrm{n} / \mathrm{cm} 2 / \mathrm{s}\end{array}$ & $\begin{array}{c}\text { Gamma flux, } \\
\text { gamma/cm2/s }\end{array}$ \\
\hline F3 & $7.61 \mathrm{E}+07$ & $1.09 \mathrm{E}+07$ \\
\hline F4 & $5.82 \mathrm{E}+07$ & $8.54 \mathrm{E}+06$ \\
\hline
\end{tabular}

Conclusion: for the range of the MCNP statistical uncertainty (2\%), neutron fluxes in Cases $1 \& 2$ are identical: in PI volume F3: $9.5 \mathrm{e} 7 \mathrm{n} / \mathrm{cm} 2 / \mathrm{s}$, in PI volume F4: $6.6 \mathrm{e} 7 \mathrm{n} / \mathrm{cm} 2 / \mathrm{s}$. For the Generic UPP with bulk shield plug, the neutron fluxes are lower: $7.6 e 7 \mathrm{n} / \mathrm{cm} 2 / \mathrm{s}$ in $\mathrm{F} 3$, and $5.8 \mathrm{e} 7 \mathrm{n} / \mathrm{cm} 2 / \mathrm{s}$ in F4. That means the GDC system does not affect the SDDR in PI.

For the gamma fluxes the MCNP statistical uncertainty is higher - reaching $10 \%-15 \%$ of relative statistical error, where gamma fluxes are the following: 1.3e7 gamma/cm2/s in $\mathrm{F} 3$ and $9.0 \mathrm{e} 6 \mathrm{gamma} / \mathrm{cm} 2 / \mathrm{s}$ in $\mathrm{F} 4$.

Radiation In-Port Cross-Talks for ITER Port Diagnostics, 22 ${ }^{\text {nd }}$ TOFE, 
SDDR results inside the PI-control volumes F3 \& F4 for the 3 cases of UPP-CXRS configurations

\begin{tabular}{|c|c|c|c|c|c|c|}
\hline $\begin{array}{c}\text { Radioactive } \\
\text { isotope }\end{array}$ & $\begin{array}{l}\text { Case } 1 \text { of UPP. } \\
\text { CXRS with GDC, } \\
\text { microSv/h in F3 }\end{array}$ & $\begin{array}{l}\text { Case } 1 \text { of UPP. } \\
\text { CXRS with GDC, } \\
\text { microSv/h in F4 }\end{array}$ & $\begin{array}{c}\text { Case } 2 \text { of UPP-CXRS } \\
\text { except GDC, } \\
\text { microSv/h in F3 }\end{array}$ & $\begin{array}{c}\text { Case } 2 \text { of UPP-CXRS } \\
\text { except GDC, } \\
\text { microSv/h in F4 }\end{array}$ & $\begin{array}{c}\text { Case } 3 \text { of } \\
\text { Generic UPP, } \\
\text { microSv/h in F3 }\end{array}$ & $\begin{array}{c}\text { Case } 3 \text { of } \\
\text { Generic UPP, } \\
\text { microSv/h in F4 }\end{array}$ \\
\hline Cr 51 & 9.76E-01 & 6.96E-01 & $9.18 \mathrm{E}-01$ & $6.70 \mathrm{E}-01$ & 7.27E-01 & $6.00 \mathrm{E}-01$ \\
\hline \multicolumn{7}{|l|}{ Mn 53} \\
\hline Mn 54 & $4.76 \mathrm{E}+00$ & $4.05 \mathrm{E}+00$ & $3.53 \mathrm{E}+00$ & $3.65 \mathrm{E}+00$ & $2.01 \mathrm{E}+00$ & $3.22 \mathrm{E}+00$ \\
\hline Fe 55 & $1.44 \mathrm{E}+00$ & $1.22 \mathrm{E}+00$ & $1.21 \mathrm{E}+00$ & $1.11 \mathrm{E}+00$ & $6.45 \mathrm{E}-01$ & $1.14 \mathrm{E}+00$ \\
\hline Fe 59 & $3.76 \mathrm{E}+00$ & $2.50 \mathrm{E}+00$ & $3.67 \mathrm{E}+00$ & $2.47 \mathrm{E}+00$ & $3.28 \mathrm{E}+00$ & $2.07 \mathrm{E}+00$ \\
\hline \multicolumn{7}{|l|}{ Co 57} \\
\hline Co 58 & $1.79 \mathrm{E}+01$ & $1.21 \mathrm{E}+01$ & $2.09 \mathrm{E}+01$ & $1.43 E+01$ & $1.44 \mathrm{E}+01$ & $1.08 \mathrm{E}+01$ \\
\hline Co 60 & $6.79 E+01$ & $5.23 E+01$ & $6.62 E+01$ & $5.19 E+01$ & $5.76 \mathrm{E}+01$ & $4.90 E+01$ \\
\hline \multicolumn{7}{|l|}{ Ni 58} \\
\hline \multicolumn{7}{|l|}{ Ni 59} \\
\hline \multicolumn{7}{|l|}{$\mathrm{Ni} 63$} \\
\hline \multicolumn{7}{|l|}{ Zn 64} \\
\hline \multicolumn{7}{|l|}{ Zr 93} \\
\hline \multicolumn{7}{|l|}{$\mathrm{Nb} 92$} \\
\hline \multicolumn{7}{|l|}{$\mathrm{Nb} 92 \mathrm{~m}$} \\
\hline \multicolumn{7}{|l|}{$\mathrm{Nb} 93 \mathrm{~m}$} \\
\hline $\mathrm{Nb} 94$ & 7.84E-04 & 9.70E-04 & 7.54E-04 & $9.10 \mathrm{E}-04$ & 7.81E-04 & 8.81E-04 \\
\hline \multicolumn{7}{|l|}{ Hf181 } \\
\hline \multicolumn{7}{|l|}{ Ta179 } \\
\hline \multicolumn{7}{|l|}{ Ta180m } \\
\hline Ta182 & 2.71E+01 & $1.80 \mathrm{E}+01$ & $2.59 \mathrm{E}+01$ & $1.78 \mathrm{E}+01$ & $2.04 \mathrm{E}+01$ & $1.43 E+01$ \\
\hline Total dose & $1.24 \mathrm{E}+02$ & $9.09 \mathrm{E}+01$ & $1.22 \mathrm{E}+02$ & $9.19 \mathrm{E}+01$ & $9.90 \mathrm{E}+01$ & 8.11E+01 \\
\hline
\end{tabular}

Conclusion: for the range of the statistical uncertainty (3\%), the SDDR results in Cases $1 \& 2$ are identical:

in PI volume F3: 124 microSv/h, in PI volume F4: 92 microSv/h. That means the GDC system does not affect the SDDR in PI. Comparison with the GUPP shows the contribution of CXRS system is 25 microSv/h in F3 and 10 microSv/h in F4 


\section{Conclusions}

- The phenomenon of in-port cross-talk was investigated for the diagnostic systems deployed in two Equatorial Port Plugs (EPP) \#17 and \#8, and for the components of Upper Port Plug (UPP) \#3.

- The Core-Imaging X-ray Spectrometer (CIXS) inside the Diagnostic Generic EPP is analysed in EPP\#17 local model, while EPP\#8 is modelled globally with C-lite v2. The CXRS-GDC in UPP\#3 was modelled using modified B-lite v. 3 model.

- Multiple sets of diagnostic equipment inserted inside the same Port Plug create additional pathways for radiation streaming along the diagnostic channels and labyrinths (e.g. optical pathways) - the reason of in-port radiation cross-talk between different diagnostic systems.

- Demonstrated that in order to take advantage of particular shielding improvements in full extent, we should also assess the mutual influence of every Diagnostic system installed inside the same port.

- This subject is important for Diagnostics designing at the stage of port integration to ensure engineering and maintenance solutions for the Diagnostic tenant systems. 